IZADP No. 3282

\title{
Are Oligarchs Productive? Theory and Evidence
}

\section{Yuriy Gorodnichenko}

Yegor Grygorenko

J anuary 2008 


\title{
Are Oligarchs Productive? Theory and Evidence
}

\author{
Yuriy Gorodnichenko \\ University of California, Berkeley, \\ NBER and IZA \\ Yegor Grygorenko \\ Citigroup Russia
}
Discussion Paper No. 3282
January 2008

\author{
IZA \\ P.O. Box 7240 \\ 53072 Bonn \\ Germany \\ Phone: +49-228-3894-0 \\ Fax: +49-228-3894-180 \\ E-mail: iza@iza.org
}

\begin{abstract}
Any opinions expressed here are those of the author(s) and not those of IZA. Research published in this series may include views on policy, but the institute itself takes no institutional policy positions.

The Institute for the Study of Labor (IZA) in Bonn is a local and virtual international research center and a place of communication between science, politics and business. IZA is an independent nonprofit organization supported by Deutsche Post World Net. The center is associated with the University of Bonn and offers a stimulating research environment through its international network, workshops and conferences, data service, project support, research visits and doctoral program. IZA engages in (i) original and internationally competitive research in all fields of labor economics, (ii) development of policy concepts, and (iii) dissemination of research results and concepts to the interested public.
\end{abstract}

IZA Discussion Papers often represent preliminary work and are circulated to encourage discussion. Citation of such a paper should account for its provisional character. A revised version may be available directly from the author. 


\section{ABSTRACT}

\section{Are Oligarchs Productive? Theory and Evidence*}

This paper develops a partial equilibrium model to account for stylized facts about the behavior of oligarchs, politically and economically strong conglomerates in transition and developing countries. The model predicts that oligarchs are more likely than other owners to invest in productivity enhancing projects and to vertically integrate firms to capture the gains from possible synergies and, thus, oligarchs can be productive. Using a unique dataset comprising almost 2,000 Ukrainian open joint stock companies, the paper tests empirical implications of the model. In contrast to commonly held views, econometric results suggest that, after controlling for endogeneity of ownership, oligarchs can improve the performance of the firms they own relative to other firms.

JEL Classification: C21, C25, D24, O17, P26, P31

Keywords: oligarch, transition, firm performance, property rights, treatment effect

Corresponding author:

Yuriy Gorodnichenko

Department of Economics

University of California, Berkeley

549 Evans Hall \#3880

Berkeley, CA 94720-3880

USA

E-mail: ygorodni@econ.berkeley.edu

\footnotetext{
* The authors thank John DiNardo, Saul Estrin, Scott Gehlbach, Patrick Kline, Michael Kruger, Maxym Kryshko, Rohini Pande, Klara Sabirianova Peter, Gerard Roland, Claudia Sahm, and the participants of the EERC/GDN, WEAI, RES, NEUDC, MPSA conferences and Michigan and especially Mark Schaffer and Jan Svejnar for useful suggestions. All remaining errors are the authors'. EERC/GDN support through Grant 02-059 is gratefully acknowledged. Gorodnichenko thanks Mitsui Life Research Center and William Davidson Institute at the University of Michigan Business School for financial support. The name of Citigroup Russia is provided with a sole and exclusive purpose to indicate the place of current employment of Yegor Grygorenko. The research presented in this work has been conducted without any support, whether direct or indirect, from Citigroup, its subsidiaries or affiliates. The views expressed reflect the opinion of the authors and cannot be attributed in any manner to Citigroup, its subsidiaries or affiliates.
} 


\section{INTRODUCTION}

Since the seminal papers by Ronald Coase $(1937,1960)$ property rights have been taken seriously in economics. Literally thousands of papers have been written to investigate the effects of property rights allocation on economic outcomes with most empirical research using data from developed economies. Yet it is the transition economies that provide the clearest picture of why and how property rights can affect economic outcomes. Their unique natural experiment highlights how patterns of property rights evolve from the inefficient forms inherited from the communist past to the more efficient forms induced by the market and reveals which forms are the most efficient and viable. Indeed, the literature devoted to analyzing and quantifying the impact of property rights allocation and security on the behavior and performance of enterprises in transition and emerging market economies has grown considerably over the last several years. ${ }^{1}$

In this paper, we show how ownership affects enterprise performance, focusing on how oligarchs_-politically and economically strong conglomerates_affect the firms they own. It is commonly believed that enterprises captured by oligarchs tend to perform poorly (e.g., Stiglitz 1999, Black and Tarassova 2002, Goldman 2004). We examine this widely shared belief and show both empirically and theoretically that the presence of oligarchs can enhance the relative performance of enterprises.

We show in a theoretical model that the evolution of property rights allocation towards integrated conglomerates led by oligarchs is not necessarily bad. Specifically, oligarchs may generally face greater returns on potential investments than low-obedient owners because of the availability of looting channels to oligarchs (i.e., existence of offshore vehicles that can accommodate profits free of taxes), magnified economies of scale and scope if looting is taken as a coordinated group action (as opposed to tax evasion by individual enterprises) and oligarchs' ability to redistribute resources within the group more efficiently than transparent outside owners. More favorable returns could, in our model, stimulate oligarchs to undertake investments in

\footnotetext{
${ }^{1}$ See, for example, Frydman et al (1999), Khanna and Rivkin (2001), Johnson, McMillan, and Woodruff (2002), Hanousek, Kocenda and Svejnar (2007), Samphantharak (2003), and Guriev and Rachinsky (2005) who examine
} 
productivity. Metaphorically, oligarchs take out a share of the common pie that would otherwise be available to the whole society, but they can also make the whole pie bigger. Overall, our theoretical results suggest that under certain conditions oligarchs have incentives to improve productivity of the firms they own. Furthermore, our model explains key stylized facts about the behavior of oligarchs. We thereby show that these behavioral patterns are rational optimizing choices of oligarchs.

On a more general level, we argue that oligarchs could have reduced the adverse effects of disorganization in the middle stages of the transition by reintegrating production chains to their market efficient levels. Indeed, if firms after disorganization of the planned economy do not have the political and economic resources to integrate downstream or upstream firms, ${ }^{2}$ it is only third parties endowed with sufficient power and resources that can integrate firms along a production chain into a conglomerate when this is warranted by the efficiency arguments (see e.g. Hart 1995). Oligarchs, formed in Russia, Ukraine and other transition economies in the mid-1990s, ${ }^{3}$ clearly had the resources to overcome the various barriers to integration of production chains and to convert potential integration synergies into profits (e.g., enforce contracts), i.e., oligarchs provided counterweight to weak institutions such as, for example, corrupt bureaucracy. Once firms are integrated, they achieve higher efficiency because oligarchs have the incentive to make relationspecific investments that generate surpluses not available in the absence of integration. ${ }^{4}$ Thus,

effects of property rights on performance. References to other noteworthy relevant works can be found in Djankov and Murrell (2002) and Khanna and Yafeh (2007).

${ }^{2}$ This appears to be the case for the vast majority of firms in transition economies including Ukraine. Documented liquidity constraints (e.g., Pissarides, Singer and Svejnar 2003), explosion of barter transactions and all sorts of arrears (e.g., Marin and Schnitzer 2002, 2005) indicate that firms face significant constraints to finance any form of integration.

${ }^{3}$ Mass privatization and lax legislation created favorable conditions for concentration of ownership in a few hands. Explaining the origins of oligarchs is beyond the scope of this paper. We refer the reader to Pappe (2000), Freeland (2000) and Hoffman (2003) who describe the emergence of oligarchs in Russia. Emergence of Ukrainian oligarchs is discussed in Investgazeta (2003), Bondarenko (2000, 2003) and Orlov (2002). Russian and Ukrainian oligarchs are similar in many respects. For example, although Ukrainian oligarchs did not have natural resources comparable to what was available to their Russian counterparts, they controlled the supplies of natural resources from Russia. In fact, several oligarchs admitted that their initial fortunes were made from importing Russian gas. So to a large extent, the origin of oligarchs is resource-based both in Russia and Ukraine. Comparative analysis of Russian and Ukrainian oligarchs would require us to write another paper. We refer the reader to Åslund (2000, 2005), Åslund et al (2001) and Havrylyshyn (2006) who compare Russian and Ukrainian oligarchy.

${ }^{4}$ The distribution of the surplus can be, however, highly uneven. Oligarchs can expropriate a disproportionately large share at the expense of other parties, such as employees and the government. Looting of firms, which gives such bad press to oligarchs, is one of the channels through which this expropriation can happen. 
formation of strong business groups controlled by oligarchs could have contributed to economic recovery in Ukraine and other transition countries.

This logic suggests that oligarchs, however demonized they are, may be socially beneficial. Olson (2000) gives a famous example of stationary bandits in medieval China. Indeed, those bandits were unpleasant governors but as long as they had shares in profits from economic activity, they enforced contracts, protected trade, and facilitated production. Thus, encompassing incentives can transform robber barons into benevolent rulers.

We test the hypothesis that oligarchs may be productive and find some support in the micro-level data for Ukrainian economy. Our empirical results, based on a sample of almost 2,000 Ukrainian open joint stock companies, suggest that oligarchs tend to improve the relative performance of the enterprises they own, which is quite contrary to the common view. Importantly, we attempt to control for endogeneity of firm ownership. Our findings have important policy implications for Ukraine and other countries with similar institutions (e.g., Russia and the Central Asian Republics) or similar organization of property rights (e.g., South East Asian and Latin American countries with highly concentrated economic and political power).

In the next section, we develop a simple theoretical model. The purpose of the model is to provide a coherent framework for organizing and formalizing verbal and informal accounts available in the literature, studying the behavior of oligarchs and drawing predictions useful for empirical work. We present our main theoretical results and show how they fit into the literature and account for the experience of transition countries and, specifically, a set of stylized facts about oligarchs' behavior. In Section 3, we describe our data, oligarchs, and discuss some institutional details about privatization. Then, we present our econometric specification and test whether oligarchs tend to raise productivity of the firms they own. We conclude in Section 4. 


\section{HOW CAN OLIGARCHS BE PRODUCTIVE?}

\section{MODEL}

Firm ownership gives control over key decisions: how to price goods, allocate profits, choose customers and suppliers, etc. Often, there is nothing criminal in transferring resources from one firm to another and fair and unfair practices are competing ways to run a business (Johnson et al 2000). For example, transfer pricing can be a legal form of shifting resources from firm A to firm B, though perhaps at the expense of firm A's shareholders, workers and local government. Anecdotal evidence from Ukrainian and Russian firms owned by oligarchs suggests that transfer pricing in various guises (e.g., overstated costs and understated sales) is a good description of how resources are tunneled away from firms. Hoffman describes one such scheme:

A common technique was called "transfer pricing". An extraction company sold oil to another company at an artificially low price, say, \$2 per barrel. The second company then sold it for export abroad at a much higher price, say $\$ 18$ per barrel. The result was that the extraction company, with all the drills, wells, fields, and workers, lost money, while the second company made a handsome profit. The wealth was transferred from one company to another, often in secret using shell companies and off-shore havens. (Hoffman 2003, p. 301)

Klebnikov (2000), Freeland (2000) and others present many similar examples. Hence, we focus on this form of looting. Of course, fully legal activity is rare in transition economies and looting could be a matter of scale rather than its existence. However, we use the stylized dichotomy of looting owner versus transparent owner to contrast the behavior of oligarchs with that of other owners.

Apart from looting, other key stylized facts observed in our data and commonly reported in the business press can be summarized as follows:

1. Oligarchs tend to choose large, not necessarily productive firms. In other words, initially oligarchs seek out large cash generating vehicles, without regard for enterprise efficiency and profitability. Indeed, Berezovsky, a notorious Russian oligarch, said that “... the first thing he wanted to take in a company was its cash flow, and only later he would be interested in owning it" (Hoffman 2003, p. 285). 
Another rationale for aiming at "big names" is the political influence that can be purchased along with the shares.

2. Oligarchs tend to create vertically integrated production chains (Guriev and Rachinsky, 2005). Visual inspection of corporate structure (see, for example, Investgazeta 2003, 2004) reveals that, in the main, the groups comprise mostly enterprises that are suppliers or consumers to each other.

3. Oligarchs can own "relatively" unprofitable firms. Here we mean accounting profits rather than true economic value added generated by the firm. For instance, Ukrainian power distribution companies controlled by oligarchs (see Bondarenko 2003 and Investgazeta 2003, 2004) consistently reported losses in 1999-2003.

4. Oligarchs often invest in improving the productivity of the firms they own. This observation is, probably, the most controversial. Yet studies such as Perotti and Gelfer (2001) and Shleifer and Treisman (2005) as well as our casual observations suggest that oligarchs make significant investments in the firms they own.

5. In the early stages of transition, firm looting appears to be particularly severe. Hoffman (2003, p. 500) observes, “... as the oligarchs gained more and more control over their companies, they became better stewards out of sheer self-interest. In the 1990s they fought bitter fights to gain majority ownership; now that it was all theirs, they were more inclined to treat the company nicely." Boone and Rodionov (2002) make a similar point.

6. Oligarchs almost invariably own foreign, typically off-shore companies. This conclusion clearly follows from inspection of the corporate structure of oligarchs' groups (see Investgazeta 2003, 2004 and Bondarenko 2003). Hoffman (2003, pp. 446-447) notes, "Khodorkovsky [one of the Russian oligarchs] built an off-shore financial network. Menatep [the core of Khodorkovsky's group] branched out to offshore havens in Switzerland, Gibraltar, the Caribbean, and other secretive locations where hundreds of millions of dollars could be easily hidden... Khodorkovsky’s far- 
reaching off-shore network was typical for Russian big business. All other oligarchs did the same thing."

We will present more evidence to support these facts below; now we develop a model that rationalizes these facts. To fix these ideas, suppose that the oligarch has the following benefit function:

$$
B_{i}=\delta S_{i}+(1-\tau)\left((1-\delta) S_{i}-C_{i}\right)-f\left(\delta-a_{i} /\left(1+a_{i}\right)\right)-1_{\delta>0} \phi,
$$

where $i$ indexes firms, $S_{i}$ is the volume of sales, $C_{i}$ is the cost of produced output, $\tau$ is the profit tax rate, $\delta$ is the degree of looting (or transfer pricing), the function $f(\cdot)$ measures the penalty for looting firms, $a_{i}$ is the markup (equivalently, productive efficiency or profit margin) parameter, $\phi$ is the fixed fee of being engaged in looting and $1_{\delta>0}$ is the indicator function equal to one if $\delta>0$ and zero otherwise. To simplify the argument, we assume that the parameters $S_{i}$, $C_{i}$ and $a_{i}$ are exogenously given to firm $i$ and $\left(1+a_{i}\right) C_{i}=S_{i}$. Finally, we assume that the penalty function $f$ is convex and strictly increasing in the looting parameter $\delta$. In addition, the penalty is zero at $\delta=0$ and infinity at $\delta=a_{i} /\left(1+a_{i}\right)$, i.e., in the long-run the oligarch cannot loot more from the firm than the cumulative stream of its profits, otherwise the firm goes bankrupt which may induce the government to severely punish the oligarch. Formally, $f \geq 0, f\left(-a_{i} /\left(1+a_{i}\right)\right)=0, f^{\prime}>0, f^{\prime \prime}>0 \quad$ and $\lim _{\delta \rightarrow a_{i} /\left(1+a_{i}\right)} f\left(\delta-a_{i} /\left(1+a_{i}\right)\right)=+\infty$. Under these assumptions, $B_{i}$ is strictly concave in $\delta .^{5}$

Importantly, we can relax the assumptions that the penalty does not depend on the firm size $S_{i}$ and that looting involves a fixed cost. ${ }^{6}$ The qualitative results do not change as long as the penalty is concave in size. This shape of the penalty function should approximate the reality well since bigger oligarchs are more influential and, hence, they are less likely to be punished severely.

\footnotetext{
${ }^{5}$ To keep the model simple, we focus on the static case. Our main qualitative results can be generalized to the dynamic case.

${ }^{6}$ Having a fixed cost helps to contrast law obedient behavior and looting since with $\phi>0$ a fraction of firms will choose to have zero looting. With $\phi=0$, all owners are going to be engaged in looting but the extent of looting would vary across owners and oligarchs would have more looting than other owners. Because we want to make a clear exposition of the dichotomy of looting vs. law obedience, we choose $\phi>0$. To reiterate, this assumption does not change our qualitative conclusions.
} 
(Khodorkovsky is the exception proving the rule. In fact, his imprisonment was because of his political aspirations and looting was only a formal reason.) Recall that oligarchs emerged as important powers because of their connections with authorities and, hence, low fixed and flow penalty relative to other owners.

Let us analyze and interpret the benefit function in (1). If the oligarch is transparent, i.e., $\delta=0$, his benefit of owning firm $i$ collapses to after-tax profit: $B_{i}=(1-\tau) a_{i} C_{i}$. Alternatively, the oligarch can transfer resources from firm $i$ by decreasing the value but not the physical volume of sales. Put differently, the books of firm $i$ record only $(1-\delta) S_{i}$ sales and the first term, $\delta S_{i}$, in (1) is the revenue of the oligarch's firm in a tax haven, which we assume to have a zero tax rate on profit. $^{7}$ Accordingly, the book before-tax profit of firm $i$ decreases from $a_{i} C_{i}$ to $\left((1-\delta)\left(1+a_{i}\right)-1\right) C_{i}$. This transfer of resources is costly as the looting oligarch incurs a flow cost $f\left(\delta-a_{i} /\left(1+a_{i}\right)\right)$ (e.g., a bribe to officials) and a quasi-fixed fee $\phi$ (e.g., flow cost of running an unproductive off-shore company to conceal profits). Optimal looting behavior $\delta_{i}^{*}$ maximizes $B_{i}$ and satisfies the following first order condition:

$$
\delta_{i}^{*}=\frac{a_{i}}{1+a_{i}}+f^{\prime-1}\left(\tau\left(1+a_{i}\right) C_{i}\right)=\frac{a_{i}}{1+a_{i}}+f^{\prime-1}\left(\tau S_{i}\right)>0
$$

and the benefit from the optimal looting is

$$
\begin{aligned}
B_{i}^{* O} & =(1-\tau) a_{i} C_{i}+\delta^{*} S_{i} \tau-f\left(\delta^{*}-a_{i} /\left(1+a_{i}\right)\right)-\phi= \\
& =(1-\tau) \frac{a_{i}}{1+a_{i}} S_{i}+\delta^{*} S_{i} \tau-f\left(\delta^{*}-a_{i} /\left(1+a_{i}\right)\right)-\phi,
\end{aligned}
$$

This outcome is compared to the fully legal (no looting, $\delta=0$ ) activity

$$
B_{i}^{*^{L}}=(1-\tau) a_{i} C_{i}=(1-\tau) \frac{a_{i}}{1+a_{i}} S_{i}
$$

The optimizing oligarch then chooses $\delta^{*}>0$ if

\footnotetext{
${ }^{7}$ Tax havens can be domestic: charities, free economic zones, etc. For instance, the oligarchic group "Dynamo" has used football club "Dynamo-Kyiv" as its tax shelter. See The Loophole Economy chapter in Freeland (2000) for eloquent examples from Russia. We assume that looting goes through understating sales. It is an easy exercise to show that the same conclusions emerge if looting is going through overstating costs. Likewise, results do not change if one off-shore company can "serve" several domestic companies.
} 


$$
\Delta_{i} \equiv B_{i}^{* O}-B_{i}^{* L}=\tau S_{i} \delta^{*}-f\left(\delta^{*}-a_{i} /\left(1+a_{i}\right)\right)-\phi>0 .
$$

Note that the oligarch's decision to run an off-shore company is a rational endogenous response to tax differentials across countries. Therefore, the model can explain stylized fact \#6.

Given these definitions and assumptions, we can prove the following proposition (all proofs are in Appendix A).

Proposition 1: Optimal looting has the following properties: (1) $\delta_{i}^{*} \in\left[0, a_{i} /\left(1+a_{i}\right)\right)$; (2) $\partial \delta_{i}^{*} / \partial a_{i}>0$; (3) $\partial \delta_{i}^{*} / \partial S_{i}>0$; (4) the probability of looting is decreasing in the fixed penalty $\phi$ and flow penalty $f(\cdot) ;(5)$ looting is increasing in the profit tax rate $\tau$, i.e., $\partial \delta_{i}^{*} / \partial \tau>0$.

Intuitively, the first three results state that 1) optimal looting is bounded by the firm's profit margin $\left.a_{i}, 2\right)$ the larger the profit margin $a_{i}$, the less noticeable is the transfer of resources and 3) the larger the firm, the larger is the gain from transferring a fixed percent of sales. These results are important in determining which firms are owned by oligarchs.

The last two results of the proposition suggest that in countries with a high penalty for looting we should observe few looting oligarchs. Likewise, transparent behavior is stimulated by low taxes. This appears to be consistent with the experience of transition countries like Estonia and Lithuania, where taxes are low and looting is highly penalized.

The last result has other important implications. First, suppose that the oligarch does not have a $100 \%$ ownership in firm $i$ and his share in the equity is $\eta$. Then after paying taxes and dividends to other shareholders, his profit is $B_{i}=(1-\tau) \eta a_{i} C_{i}$. Define effective tax rate as $\tilde{\tau}=1-(1-\tau) \eta$ so that $B_{i}=(1-\tau) \eta a_{i} C_{i}=(1-\tilde{\tau}) a_{i} C_{i}$ and apply the last result of the proposition. Then the larger the oligarch's share $\eta$ in the equity, the smaller is the effective tax rate and the weaker the incentive he has to loot the firm. In the beginning of the transition, would-be oligarchs very rarely owned significant shares in firms and, consequently, looting was particularly acute in that period. As they accumulated wealth and shareholdings, they appeared to become less 
aggressive. This theoretical prediction rationalizes stylized fact $\# 5 .{ }^{8}$ Second, suppose that $S_{i}-C_{i}$ in (1) measures the net present value of owning a firm. Then a high $\tau$ can capture a low probability of owning a firm in the future, i.e., short duration of ownership. Hence, reprivatization threats and political upheavals can make looting an optimal behavior. Again, in the beginning of the 1990s oligarchs were more uncertain about their property rights than in present days and, hence, they looted aggressively, which is consistent the stylized fact \#5.

Next we turn to the oligarch's choice of which firms to own.

\section{Proposition 2:}

1. Suppose that the sales of firm $i$ are proportional to $K_{i}$, the equity capital of firm $i$, i.e., $S_{i}=\kappa K_{i}$. Then the oligarch's return on capital is weakly increasing in the firm size measured by sales. The transparent owner's return on capital is independent of firm size.

2. The oligarch has a weakly higher return on capital in productive firms than the transparent owner.

Intuitively, the firm size matters for oligarchs because the penalty for looting per sales is decreasing in sales. Since oligarchs have a higher return on capital (ROC) in large firms, they are willing to pay a higher price for these firms. In contrast, transparent owners are indifferent between large and small firms as long as they have the same productivity. Hence, it should be the case that oligarchs tend to own large firms. This is in agreement with stylized facts \#1 and \#3. Indeed, power distributing companies, which are often owned by oligarchs in Ukraine and Russia, are heavily regulated and their reported profits tend to be small. However, their volume of sales is immense thus giving oligarchs the incentives to acquire a stake and control these firms (recall Berezovsky's thirst for large cash flows, which are not directly related to productivity). This result is important for our empirical work when we develop a selection equation to model endogeneity of firm ownership.

To understand the second part of the proposition, note from (3) and (4) that for any increase in productivity $a_{i}$ and for any given looting parameter $\delta$, the oligarch captures a direct gain in after-tax profits, receives a larger transfer to his off-shore company (because he transfers a

\footnotetext{
${ }^{8}$ The model can be easily extended to analyze protection of minority shareholders. For example, a large $\phi$ and steep $f$ can be interpreted as good protection of minority shareholders. Poor protection of minority shareholders is not
} 
fixed percent of sales to his off-shore company) and pays a smaller penalty for looting $f\left(\delta-a_{i} /\left(1+a_{i}\right)\right)$ as the profit leakage becomes less noticeable.

We now generalize the model and allow firms to invest in productivity-enhancing projects. We assume that each firm can undertake a revenue-enhancing investment which leaves the cost of input $C_{i}$ unaltered and boosts its productivity from $a_{1 i}$ to $a_{2 i}$ with $a_{2 i}>a_{1 i}$. The flow cost of the project is $\chi C_{i}$. Any rational owner should make the investment if it increases profits. As the following proposition shows, oligarchs are more likely to make such an investment.

Proposition 3: The oligarch makes (weakly) larger investments than the transparent owner.

This proposition shows that oligarchs have stronger stimuli to improve firm productivity. The reason why oligarchs are more willing to invest is that they have a higher return on firm size and productivity than transparent owners. Specifically, with higher productivity, oligarchs can hide tunneling more easily. Since they transfer a fixed percent of sales to off-shore companies and looting is increasing in productivity, for every increase in productivity they make a larger transfer of firm resources to tax havens, thus avoiding high taxes at home and receiving a higher return on investment. In contrast, transparent owners have to share the gains from increased productivity with the government and thus have weaker incentives to invest. This explains stylized fact \#4.

In theory, the investing oligarch may be so productive that he pays more in taxes than the transparent owner who does not invest. Observe that for a fixed $\delta$, the investing oligarch generates higher profit and thus pays higher taxes. On the other hand, higher productivity leads to larger looting $\delta$, thereby decreasing the tax base. If the gain in productivity is sufficiently large and looting is relatively small, the oligarch undertaking the investment would generate more tax revenues than the transparent non-investing owner. The following proposition provides conditions for when this can happen. 
Proposition 4: For a sufficiently large increase in productivity, the investing oligarch pays more in taxes than the non-investing transparent owner if and only if the marginal flow penalty $f^{\prime}$ is elastic.

We now turn to the oligarch's inclination to vertically integrate firms. There are two firms: upstream (U) and downstream (D) with productivity parameters $a_{U}$ and $a_{D}$, respectively. The upstream firm sells its output to the downstream firm so that the sales of the upstream firms are equal to the costs of the downstream firm. To capture the complementarity of assets, relationspecific investments and other forms of synergy, we assume that in the case of integration (I) productivity is higher than in the no-integration case (e.g., Klein, Crawford and Alchian 1978), that is, $a_{I}>a_{U}+a_{D}+a_{U} a_{D}$. Consistent with focusing on the revenue side, we assume that integration does not affect the cost of the upstream firm. Integration of firms is costly because of regulation obstacles, reorganization disruptions, agency costs, etc. Hence, we assume that the flow cost of integration is $\chi C_{U}$. The no-looting after-tax profits are

$$
\begin{aligned}
& \mathrm{U}: \pi_{U}=(1-\tau)\left(S_{U}-C_{U}\right)=(1-\tau) a_{U} C_{U}, \\
& \mathrm{D}: \pi_{D}=(1-\tau)\left(S_{D}-C_{D}\right)=(1-\tau)\left(S_{D}-S_{U}\right)=(1-\tau) a_{D}\left(1+a_{U}\right) C_{U}, \\
& \mathrm{I}: \pi_{I}=(1-\tau)\left(S_{D}-C_{U}\right)=(1-\tau) a_{I} C_{U} .
\end{aligned}
$$

An owner will choose to keep firms separate or integrate them into a conglomerate depending on which scenario yields a larger profit. The relevant comparison is again the looting oligarch versus the transparent owner. The change in the after-tax profit of the transparent owner who integrates firms is $\Delta^{L}=\pi_{I}-\pi_{D}-\pi_{U}-\chi C_{U}$. (We assume that the cost of investment is not tax deductible.) If $\Delta^{L}>0$, the transparent owner integrates firms, captures the gains in productivity and generates higher tax revenues.

For the oligarch, the change in benefit is

$$
\Delta^{O}=B_{I}-B_{D}-B_{U}-\chi C_{U}
$$

where $B_{I}, B_{D}$, and $B_{U}$ are the oligarch's benefits from running integrated, downstream and upstream firms, respectively. Using Propositions 3 and 4, we prove the following result. 


\section{Proposition 5:}

1. The oligarch has greater incentives to integrate firms vertically if assets are complementary, investments are relation specific or there are other synergies from the merger. Specifically it always holds that $\Delta^{O} \geq \Delta^{L}$

2. For a sufficiently large increase in productivity, the integrating oligarch generates higher tax revenues than the transparent owner who does not merge firms if the marginal penalty for looting $f^{\prime}$ is elastic.

There are several reasons why the oligarch wants to integrate firms. First, he economizes on the fixed cost of running an off-shore company. Second, by raising productivity from $a_{D}$ and $a_{U}$ to $a_{I}$ the oligarch can more easily tunnel a fixed percentage of sales and transfer it to his offshore company. (Note that the oligarch has incentives to integrate firms even in the absence of synergies.) Recall that the oligarch's ROC is increasing in the firm size and productivity. Because synergies from the merger raise the overall productivity of the formed conglomerate, the oligarch's benefit increases more than that of the transparent owner and, therefore, under certain combinations of productivity parameters and costs of merger, the oligarch rationally chooses to invest when the transparent owner does not. Given the fact that the oligarchs are likely to face smaller integration costs because of their political connections, they effectively have even greater incentives to integrate firms. Proposition 4 rationalizes stylized fact \#2.

The second part of the proposition addresses the question of whether the government should stimulate integration. The answer is clearly "yes" if the owners are transparent because mergers increase the tax base. What about the oligarchs? The answer depends on the relative strength of the productivity gains and looting motives. Like in our analysis of investment, elastic marginal penalty for looting is the necessary condition for tax revenues to increase when the firms are integrated.

Note that, although we focus on synergies from vertical integration, our analysis can be easily extended to synergies from horizontal integration. Because transaction costs literature often does not make much distinction between vertical vs. horizontal integration when it discusses synergies from integration, one can simply re-label upsteam (U) and downstream (D) firms with left (L) and right (R) firms and apply the same intuition and algebra to horizontal integration. This continuity in the argument is useful because oligarchs can build both vertically integrated 
and horizontally integrated empires but the choice of oligarchs' strategy does not affect our qualitative theoretical predictions about occurrence and benefits of integration.

Propositions 3 and 5 combined suggest that oligarchs, ceteris paribus, will tend to generate surplus, which would otherwise go unnoticed, by integrating vertical production chains and investing into profitable projects. As long as the amount looted by the oligarchs is less than the incremental surplus for the economy, these activities are socially beneficial (Propositions 4 and 5). The incentive for oligarchs to engage in such ventures is rooted in the existence of some "tax-free" extra profit which is looted off-shore. The relative efficiency of oligarchs compared to transparent owners is thus directly dependent on the level of $\delta^{*}$, among other things. We can label this type of efficiency as the "first-order" efficiency.

Hart (1995), however, argues that although some basic forms of property rights arrangements can yield better results than others, none is able to produce the first-best levels of investment and maximize trade surplus in absolute terms. We show in Appendix B that under certain conditions oligarchs can not only be relatively more efficient, but may also demonstrate absolute efficiency in choosing investment levels and maximizing production surplus. Specifically, this additional efficiency derives not from the level of $\delta^{*}$, but from the ability of the oligarch to vary $\delta^{*}$ with the level of investment and sales (the "second-order" efficiency). This result suggests that in some cases the oligarch's ownership can be superior to upstream-, downstream- and no-integration arrangements of property rights. Hence, business conglomerates controlled by oligarchs can be competitive in the long run as they can reach the first-best levels of relation-specific investments.

The predictions of this stylized static partial-equilibrium model are consistent with reality. Oligarchs indeed tend to own larger firms. Although in practice oligarchs tend to own profitable firms, they do own unprofitable firms as well. If the firm has high productivity (or markup), it is easier to hide a transfer of resources and report "standard" profits. In economies with low taxes and a high penalty for looting, oligarchs rationally choose to stay within legal limits. Oligarchs tend to loot aggressively firms in which they have a small stake. The model also 
explains why profits of a single firm owned by an oligarch can fail to reveal information about productivity of the oligarch's chain of firms as a whole and measured productivity can be low. The model organizes many ideas and verbal accounts from the literature (e.g., Boone and Rodionov 2002) in a coherent, parsimonious framework. With very few 'degrees of freedom', our simple model rationalizes all key stylized facts about oligarch ownership and provides intuition for both static and dynamic aspects of oligarchs' behavior.

The model provides unambiguous guide on selection of firms into oligarchic groups and the model points out possibilities of how oligarchs can be relatively good owners. Specifically, the model shows that oligarchs can be parasites in the sense that they do not generate additional surplus and simply redistribute profits. Yet, the model also demonstrates that if there are synergies from integrating production chains or productivity enhancing investments, oligarchs are likely to generate surplus and benefit the society. ${ }^{9}$ As we argue below, oligarchs could have played an important role in reintegration of production chains and, thus, could have significantly contributed to the economic recovery of transition economies. Finally, the model can explain why conglomerates led by oligarchs may be a viable form of organization even as the economy develops and more progressive institutions enter the scene.

\section{DISCUSSION AND CONTEXT}

Using our framework, we can construct a consistent story of the development of industries in the former Soviet Union (FSU) in the 1990s. In the Soviet era, the state was the sole owner of residual control rights in all medium and large-sized enterprises. The system was designed to fulfill the plan and maximize output of certain top-priority goods and services (in order of importance military sector products, industrial construction, basic necessities). The degree of vertical integration was close to its technological maximum and the whole system was driven by a state plan. Although the plan was supposed to be a product of objective budgeting, upstream firms, which produced products from a top-priority list, and their immediate contractors had significant

\footnotetext{
${ }^{9}$ Furthermore, if we interpret $\tau$ as the cost of running business in a country, that is $\tau$ includes not only fiscal revenue of the government but also all other losses (e.g., waiting time), than oligarchs can be useful to society because they run
} 
bargaining power over the downstream firms. This resulted in considerable overinvestment in physical capital in heavy industries and underinvestment in most consumer-oriented industries (e.g., Kornai 1992, Gaidar 1997).

Upon the break-up of the USSR, the state lost much of its power and de facto residual rights of control were appropriated by the management of respective firms. This corresponds to the non-integration ownership structure discussed in the previous section. Underinvestment did indeed occur and the total value of specific relationships within the economy, as well as its output, declined dramatically (see Figure 1). It is worth emphasizing that underinvestment was equally acute for heavy industries, as well as for the light industries - in the case of the latter it was associated with more explicit underinvestment in new technology and new capacities, in the case of the former it took the form of insufficient investment into the restructuring of installed capacities and refurbishing the technological process.

Disorganization of production is the leading explanation of the output's U-shaped dynamics in transition countries. Blanchard and Kremer (1997) suggest that private potential uses of resources outweigh conventional state uses and divert inputs from the public sector of the economy. Given specificity of inputs, this generates a downturn in output. In the course of time, private uses improve and total output rises. ${ }^{10}$ Roland and Verdier (1999) develop a search model where firms of two types, "low productivity" and "high productivity", engage in vertical productive relationships. The fall in output is explained as a diversion of resources from production to search for better production matches. This model also predicts the U-shape trajectory in output. Although both models are built on solid micro-foundations, neither can explain who restores production chains, why it takes more time to recover for some countries than others, and why firms did not reintegrate quickly after liberalization. ${ }^{11}$ One of the contributions of

business at a lower cost. Given this interpretation, tunneling resources may mean that oligarchs shift resources to safer locations or activities. In addition, it is not clear that government uses fiscal revenue more efficiently than an oligarch.

${ }^{10}$ Marin and Schnitzer (2005) argue that the burst of barter in transition economies was a response to hold-up problems induced by the disorganization.

${ }^{11}$ Empirical analysis of disorganization theories (e.g., Konings and Walsh 1999, Recanatini and Ryterman 2000, Johnson, McMillan, and Woodruff 2002, Marin and Schnitzer 2002, 2005) focused on security of property rights while we focus on the effects of their arrangements. 
this paper is providing an account of who improves private uses and who makes efficient matches of firms. We argue that oligarchs in Ukraine and other FSU countries could have been the anonymous revitalizing force in disorganization models and, thus, oligarchs could have contributed to economic recovery in the FSU countries by reintegrating production chains to levels efficient in the market economy. This is complementary to the theory advanced by Boone and Rodionov (2002) who argue that concentration of ownership in Russia stopped rent seeking and started the economic recovery after $1998 .^{12}$

To map the model to empirics, we need to specify who the oligarchs are and how these oligarchs improve performance. We first define who can be labeled an "oligarch" in the context of the Ukrainian economy. Clearly, it should be someone who 1) employs enough financial resources to appropriate controlling stakes and control the management in a number of large vertically related enterprises, 2) has enough political weight and lobbying ability to secure attained residual control rights, and 3) possesses enough bargaining power to implement redistribution of cash flows within the group and enforce internal and external contracts. Specifically, an entity is called an "oligarch" if it meets the following criteria (similar to those in Pappe 2000): 1) the entity controls at least three enterprises, 2) the entity has at least one for-profit enterprise, 3) enterprises controlled by the entity regularly interact and coordinate their businesses (technology, marketing, etc.) and the entity controls decision-making in these enterprises, and 4) the entity has at least one representative in the parliament or government that is legally or publicly associated with this entity or the group controlled by it. The last criterion filters out groups that have no sufficient political power and, thus, are extremely susceptible to political or legal action by competitors, which would endanger contract enforcement or even ownership claims.

The next step is to analyze particular mechanisms by which an "oligarch" can improve enterprise performance and induce larger investment. We have uncovered the following plausible basic mechanisms: 1) pure coordination — improved group-level planning and management

\footnotetext{
${ }^{12}$ Braguinsky and Myerson (2007) provide an alternative account where oligarchs caused the recession in Russia and similar countries. In their theoretical model, the collapse of the economy is caused by inability of oligarchs to store
} 
efficiency, related to observability and verifiability of investments; 2) contract enforcement imposition of a binding discipline on group enterprises and effective enforcement of delivery by outside contractors, which ensures more certainty in the trade relationship and makes outside options less binding; 3) internal capital markets - markets established within a group to ensure that marginal productivity of investments is equalized throughout the group and first-best levels of investment are attained; 4) access to external finance - the ability of an "oligarch" to provide cheaper and better access to external lending sources for all members of the group; 5) protection — oligarchs can be superior in protecting their profits from the grabbing hand of the government. Since all channels are highly interconnected, we do not separate them and instead focus on the aggregate effect.

In brief, our model predicts that oligarch choose firms non-randomly with the bias towards larger and more productive firms. The model also suggests that under certain circumstances oligarchs can be relatively good owners. For example, oligarchs creating closed groups of vertically integrated enterprises can be associated with increased volumes of investment and improved enterprise performance. The model also emphasizes that oligarchs have incentives to be bad owners. For example, political favoritism can reduce the ownership horizons for oligarchs and induce aggressive looting. Which motive dominates is an empirical question that we try to address in the next section.

\section{AN EMPIRICAL TEST OF THE PRODUCTIVE OLIGARCH THEORY}

While our model yields a number of potentially falsifiable predictions, we are unfortunately not able to test many of them because of the enormous size of the industrial groups (up to 800 legal entities), unobservable nature of looting, lack of consolidated reporting, and presence of numerous trade houses and off-shore vehicles within the conglomerates. As a result, we focus on the following testable prediction: the presence of an oligarch improves the performance (productivity)

their wealth safely in the early stages of transition. This inability leads to ferocious asset stripping and capital flight and thus output decline. As risk-averse oligarchs accumulate safe reserves, the economy experiences a turnaround. 
of each enterprise entering the group. To test this hypothesis, we estimate a production function and, controlling for selection, examine whether the productivity of firms owned by oligarchs is, ceteris paribus, higher than that of firms not owned by oligarchs.

\section{DATA}

We rely on two original sources of information: the State Stock Market and Securities Commission (SSMSC) and the State Statistics Committee (SSC). Both agencies collect firm-level financial, ownership and operating data on an annual basis and maintain comprehensive databases: the former carries out this function for all entities that are either incorporated as open joint stock companies (OJSCs), or issue publicly traded securities; the latter collects data for all legally registered businesses in Ukraine. The two datasets are merged by unique firm identification codes.

The SSC collects a relatively small set of economic indicators such as the number of employees, sales, value added, and capital assets. The key feature of this data set is that it starts in 1993 (after liberalization and just before privatization) with a reasonably large cross section of firms. The data collected by the SSMSC are, by far, more informative, but complete crosssections of OJSCs are available only for recent years. SSMSC requires firms to disclose externally audited balance sheets and income statements, the main business competitors and partners, management board composition and other characteristics of the firm. The key variable from this data set is ownership structure: shares and owners are identified (name, firm identification code, country of origin, share). We complement this information with detailed ownership records for 2002 in the database maintained by the Association of Registrars of Ukraine (ARU) and the State Tax Administration of Ukraine (STAU). We utilize these data sets to track ownership relationships between enterprises and business groups, i.e., we separate entities controlled by “oligarchs" from common publicly or privately held ventures and state-owned enterprises.

Although a priori effects of property rights allocation and security on a firm's performance and investment pattern are expected to be significant regardless of the firm's size, we 
limit the scope of our analysis to fairly large enterprises for several reasons. First, small enterprises are less likely to be involved in business conglomerates, as their expected cash generating ability (which is blatantly related to firm size) is relatively small in comparison to the transaction costs of integration and coordination. Second, small enterprises in Ukraine are subject to far less strict disclosure requirements than their medium and large-size counterparts. Third, reliability of financial information provided by the small companies is presumably much poorer because of less stringent reporting requirements, lax accounting procedures, and much weaker public control. Hence, we consider firms with at least 500,000 UAH (approximately USD $100,000)$ in assets.

Our working data set consists of firms present in both i) the SSC data base in 1993 and ii) the SSMSC dataset in 2002. The size of this sample is 1,917 firms while the size of the SSC data set in 1993 is approximately 7,000, and the size of the SSMSC data set in 2002 is approximately 8,000 firms. In the course of privatization, large firms were required to be incorporated before they were sold, while relatively small enterprises did not have to be incorporated. Even firms $100 \%$ owned by the state are incorporated in anticipation of future privatization. Thus, we are more likely to find larger firms in this sample than in the population. Attrition effects are likely to be small in determining the composition of the sample because large firms are very unlikely to go bankrupt in Ukraine predominantly for political reasons and weak bankruptcy laws. ${ }^{13}$ In accordance to the Ukrainian legislation, essentially all firms in our sample were privatized in open auctions and all investors were provided with equal access to information about firms.

At the time of privatization, oligarchs were typically outsiders to the firms they bought, i.e., the managers and other insiders were typically not affiliated with oligarchs. Therefore, oligarchs did not have any material non-public information about the enterprises and it was not required, in fact. There was no need to value the companies being bought as the prospective buyer faced no risk to overpay: state property was sold for a nominal, hugely undervalued price and a 
successfully closed deal would result in a non-negative return. With cost of purchasing a medium and a large enterprise being immaterially different (even quasi-fixed), the well-connected wouldbe oligarch would more likely target the latter for acquisition as it promised higher gain in the absolute terms. The price was particularly low for firms with liquidity problems. So the typical strategy was to pick up all the biggest firms around and to do it quickly before someone else steps in. Hoffman (2003, p. 205) provides a vivid example of how oligarchs acquired enterprises:

Like many others [oligarchs], Khodorkovsky was shooting in the dark. He could not figure out which factories were potentially lucrative, so he bought many... Khodorkovsky purchased large blocks of shares in timber, titanium, pipe, copper smelting, and other industries, more than one hundred companies in all... He hired Andresen Consulting to survey the crazy quilt industry he had assembled and the management consultants told him he had gathered up the equivalent of a South Korean conglomerate.

So little information was often available that investors “... often knew nothing about the companies they were buying. Even an oil major like Lukoil had barely one page of financial data to share with investors. (Hoffman 2003, p. 207)." Value acquired in this race was to be assessed only much later. Because similar stories can be told about the Ukrainian privatization, we believe that, given information constraints, oligarchs relied on simple observable characteristics of the firms (e.g., firm size, volume of sales, industry) rather than on unobservable characteristics such total factor productivity. Importantly, there was little mobility of controlling stakes in the property after privatization for our firms so that oligarchs did not acquire their property after the economy started to recover and it is unlikely that oligarchs bought firms after somebody else turned the firms around and made them attractive assets.

Oligarchs are the key ingredient in our analysis. Our working definition of oligarchs (see previous section) identifies 13 oligarchic groups, with System Capital Management led by Rinat Akhmetov being the largest group in Ukraine (Table 1). In total, they control 276 firms (14\% of the sample). We draw on various sources-most importantly the SSMSC/ARU/STAU data and business press - to determine if a given enterprise is owned by an oligarch. This task is

\footnotetext{
${ }^{13}$ Sample selection is negligible for most specifications we consider as the coefficient on the Mills ratio is not statistically different from zero.
} 
particularly challenging since oligarchs very rarely own OJSCs directly, rather they typically own OJSCs though a chain of holdings, intermediate firms, and off-shore companies. ${ }^{14}$

Figure 2 presents a typical branch of a conglomerate owned by a Ukrainian oligarch. ${ }^{15}$ Clearly, the branch is a representative vertically integrated chain. Note the presence of off-shore companies, which is an essential feature of all oligarchs. Parallel examples from Russia and other FSU countries are abundant, e.g., Lukoil of Alekperov and Yukos of Khodorkovsky. ${ }^{16}$ Note that oligarchs in the post-Soviet countries have much in common with the Korean chaebol, Japanese keiretsu, or other 'family'-like business groups across the world (La Porta, Lopez-De-Silanes, and Shleifer 1999, Khanna and Yafeh 2007).

The main descriptive statistics are reported in Table 2. On average, the firms owned by oligarchs have larger profits than firms in the control group. Yet, the large standard deviation indicates that loss-making firms are not uncommon in oligarchic groups.

Oligarchs tend to have stakes in larger firms. In our sample an average oligarch-owned firm has triple the amount of total assets on its balance sheet compared to its counterpart from the control group. The ratio for the number of employed is of the same rank: 1520 employees for an average firm belonging to some business conglomerate versus only 514 for a typical enterprise in the control group. In 2002, an average firm in an oligarch group has a far "richer" capital endowment: the net book value of fixed assets is approximately three times larger for such an enterprise than for a typical control group representative. ${ }^{17}$ The gap does not seem so large when put into per employee terms: the amount of capital per employee is only $9.4 \%$ larger for an oligarch-owned firm than for non-oligarch-owned firms. This difference does not seem large enough to explain fully the $23 \%$ difference in value added per employee between these two groups of firms.

\footnotetext{
${ }^{14}$ With respect to Berezovsky, one of the most prominent Russian oligarchs, Hoffman (2003, p. 401) observes, “... his [Berezovsky's] holdings were a mysterious empire shielded by layers of shell companies and off-shore havens."

15 More structures for oligarchic groups can be found in Investgazeta (2003, 2004) and Bondarenko (2003). Analogous structures for Russian oligarchs can be found in Pappe (2000).

${ }^{16}$ See, for example, Hoffman (2003) and "In the land of Oligarchs" by Peter Maass in New Your Times Magazine (Aug 1, 2004).
} 
In terms of industry concentrations, oligarchs have the largest representations in the metal and chemical industry. This is also hardly surprising because these industries are export oriented and, as such, are the most secure source of hard currency cash flows. Since most enterprises in these industries are in the Eastern Ukraine, oligarchs have the largest share of firms owned in the Eastern Ukraine. ${ }^{18}$

We believe that all of these basic observations can be plausibly applied to the Ukrainian economy at large without a loss of significance (at least to the manufacturing sector). Although the constructed sample contains only open joint stock companies, it captures most of the national 'blue chips'. The sampled firms account for approximately $12.5 \%$ of the Ukrainian GDP in 2002 and for about $18.9 \%$ of the value added in the industry and services. This is a large share indeed, though not unexpected as open public companies produce slightly more than $30 \%$ of the Ukrainian GDP and our sample comprises the largest quarter of them. Therefore, the sample is interesting from both academic and policy standpoints.

\section{ECONOMETRIC METHODS AND SPECIFICATION}

If ownership were assigned at random, difference in sample means of treatment (owned by oligarchs) and control (not owned by oligarchs) groups would be a consistent estimate of the average treatment effect of being owned by an oligarch. Unfortunately, Table 2 clearly reveals that the assignment is not random: oligarchs tended to buy large firms. Since selection on productivity and other unobservables was not likely during privatization, differences in observables characteristics can be a particularly important source of bias in the estimates of the treatment effect. Indeed, value added of large firms (more than 1000 employees in 1993) grew $35 \%$ less than that of smaller firms (less than or equal to 1000 employees in 1993) over 19932002. Because oligarchs tend to own large firms, differences in the composition of the treated and

\footnotetext{
${ }^{17}$ Of course, one should take these estimates of capital stock quite cautiously. Yet, given no material differences in accounting practices of oligarchs and the control group, the number indicated above should give a meaningful estimate of the gap between the firms in each group.

${ }^{18}$ Note that other industries and sectors such as transport and agro-business are not in our sample. We have to drop observations in these sectors because we did not have data for these firms in 1993. However, oligarchs do own firms in these sectors. See Figure 2 for an example.
} 
control groups is likely to translate into a downward bias in the OLS estimates of the treatment effect.

We employ two estimators to consistently estimate the average treatment effect (ATE) of oligarchs on firm performance: instrumental variables (IV; e.g., Wooldridge 2002) and selectioncorrected treatment effects (SEL; e.g., Heckman 1978, Maddala 1983) model. Although IV and SEL are built on different assumptions (e.g., Heckman and Navarro-Lozano 2004), in practice they often give similar answers (Vella and Verbeek 1999). Wooldridge (2002), however, notes that IV is more robust to various misspecifications. On the other hand, Heckman and NavarroLozano (2004) argue that SEL makes weaker assumptions and allows dependence of outcomes on treatment even after conditioning on unobservables. Both methods fix an apparent flaw in observational studies: non-random assignment of treatment.

Fortunately, we can trace firms from pre-privatization days (i.e., before 1994) to present time. In 1993, essentially all large firms were state owned. Thus, we have some uniformity in the pre-treatment. Importantly, prices were liberalized before 1993 so that firm performance in 1993 was a better indicator of future profitability than performance in earlier periods when prices were largely regulated. Hence firm characteristics in 1993 were important for oligarchs in 1995-1999 when most firms were privatized. By 2002, large firms have been by and large incorporated and thus they show up in our sample.

As for the model governing oligarch's choices, our theoretical results indicate that firm size and productivity are the relevant variables (although institutional details of privatization suggest that productivity could have been less important because oligarchs were outsiders and could rely almost exclusively on observable characteristics of the firms, e.g. firm size). We measure productivity as the output to labor ratio, which is a proxy for labor productivity. Firm size measured by sales is particularly important as it differentiates transparent owners from oligarchs. In addition, we include a firm's capital assets to capture the asset stripping motive with larger capital stock being ceteris paribus more attractive for oligarchs. Capital assets also serve as proxies for the firm size. Profitability in 1993 appears to be a poor predictor of a firm's cash 
generating ability because in 1993 most firms had a heavy burden of social commitments inherited from the Soviet times, e.g., financing kindergartens and hospitals for their employees. As a result, our selection (SEL) or first stage (IV) equation is

$$
\text { OLIGARCH }_{i}=\Phi\left(\alpha_{1} \ln \text { Sales }_{i}^{(93)}+\alpha_{2} \ln L_{i}^{(93)}+\alpha_{3} \ln K_{i}^{(93)}+\boldsymbol{X}_{i}^{(93)} \gamma+\varepsilon_{i}\right)
$$

where $i$ indexes firms, OLIGARCH is a dummy variable equal to one if the firm is owned by an oligarch and zero otherwise, Sales ${ }_{i}^{(93)}$ is sales in 1993, $L_{i}^{(93)}$ is the number of employees in 1993, $K_{i}^{(93)}$ is the beginning-of-the-year value of capital in $1993, \boldsymbol{X}$ is a set of industry and regional dummies for 1993, and $\Phi$ is the c.d.f. of the standard normal distribution. Note that because we use variables in logs, specification (6) is the reduced form of a specification that, in addition to the level of the variables, includes logs of the output/capital, output/labor, and capital/labor ratios. If productivity $\ln \left(\right.$ Sales $\left.^{(93)} / L^{(93)}\right)$ is important, we should expect a negative sign on labor.

To measure the effect of the oligarch on firm productivity, we estimate the CobbDouglas production function in growth rates of the respective variables between 1993 and 2002. The precise specification is as follows:

$$
\log \left[V A_{i}^{(02)} / V A_{i}^{(93)}\right]=\alpha_{K} \log \left[K_{i}^{(02)} / K_{i}^{(93)}\right]+\alpha_{L} \log \left[L_{i}^{(02)} / L_{i}^{(93)}\right]+\beta \cdot O L I G A R C H_{i}+\boldsymbol{X}_{i} \gamma+u_{i}
$$

where $V A_{i}$ is the value added, $K_{i}$ is the capital (fixed assets beginning of the period), $L_{i}$ is the average number of employees, $\boldsymbol{X}_{i}$ is the set of regional and industry dummies. ${ }^{19}$ Importantly, because we estimate the production function in log differences, we eliminate firm specific productivity and therefore avoid endogeneity of inputs arising from the transmission bias identified by Marschak and Andrews (1944). Furthermore, note that using growth rates over long horizons attenuates the possible adverse effects of measurement errors in the right hand side variables, especially capital (see Griliches and Hausman 1986). The estimate of $\beta$ measures the effect of the oligarch's ownership on the firm's productivity. This specification is similar to the

\footnotetext{
${ }^{19}$ We find similar results when we use sales instead of value added as the dependent variable. However, because value added provides a better lower bound on the effects of oligarch ownership (see the next footnote), we prefer estimates based on value added. In addition, as argued in Gorodnichenko (2007), including value (rather than volume) of the material input as a regressor in equation (7) might be problematic from econometric standpoint for typical production function regressions.
} 
one used by Guriev and Rachinsky (2005). The SEL model estimates (6) and (7) simultaneously. In contrast, IV uses estimated probability from (6) to instrument OLIGARCH in (7). To reiterate, we derive these exclusion restrictions from our theoretical model.

\section{RESULTS}

The estimates of the first stage regression (6) are presented in Table 3. Consistent with our theoretical model, the volume of sales and capital stock are important determinants of the oligarch's ownership. Interestingly, employment is irrelevant provided capital and sales are included. This suggests that labor productivity, which in contrast to sales is not directly observable, was not of particular importance in the oligarch's decision to own a firm. This appears to be consistent with anecdotal evidence. We also do not find any specific regional preference in oligarchs' choices. However, owning firms in the metals industry appears to be an oligarch's desideratum. Machine building, light/food and chemical industries are also relatively more attractive to oligarchs than firms in the energy and services sectors. Overall, the model is statistically significant at all conventional significance levels and it has a reasonable fit.

Table 4 presents the estimates for the production function given by equation (7). We include only one regional dummy Kyiv because other regional dummies have economically small and statistically insignificant coefficients. When the model is estimated by OLS (column 2), the coefficient on OLIGARCH is positive but not statistically significant. The coefficients on labor and capital are statistically significant with sizes typically found for production functions estimated on long differences of output and inputs (e.g., Griliches and Hausman 1986 and Tybout and Westbrook 1996). The magnitude of the coefficient on the labor growth rate reflects the fact that labor proxies for all variable inputs and unobserved effort and utilization rates.

OLS does not correct for the endogeneity of OLIGARCH; thus, finding a weak difference in productivity does not refute our argument. Once endogeneity is taken into account, oligarchs do appear to have a higher productivity than other owners. Specifically, IV and SEL estimates indicate that, ceteris paribus, oligarchs have a 50\%-70\% higher value added growth rate than non- 
oligarchs over 1993-2002. ${ }^{20}$ Although the size of the coefficient may appear to be somewhat large, it is plausible in the Ukrainian context. Recall that the economic collapse in the early 1990s (GDP had fallen $60 \%$ by 1997) led to very low capacity utilization rates. There is extensive anecdotal evidence that inactive and largely idle plants were turned into three-shift plants with the change of owners. ${ }^{21}$ Hence, a $50 \%$ expansion of output is more than likely. Also, our finding is consistent with Guriev and Rachinsky (2005) reporting that in 2001/2002 sales grew 10\% faster in firms owned by Russian oligarchs than in other domestically owned firms. It is unlikely that the gains in value added were generated from increased market power because industries with high incidence of oligarchic ownership are strongly export oriented and the majority of the external markets are highly competitive, e.g., steel market.

Note that the correlation $\rho\left(u_{i}, \varepsilon_{i}\right)$ is statistically significantly different from zero (column 5). Likewise, the Hausman test (column 3) rejects the equality of OLS and IV estimates. Thus, estimating (7) by OLS does not yield a consistent estimate of $\beta$. A negative correlation between $u_{i}$ and $\varepsilon_{i}$ suggests that oligarchs pick underperforming firms and then improve their productivity. One might have expected a positive correlation because, for example, oligarchs could pick firms that are likely to grow faster ("cherry picking"). This reverse causality from productivity to oligarch ownership would generate a positive correlation and, hence, would induce an upward bias in the OLS estimates. Likewise, if firms owned by prospective oligarchs were hit with positive productivity shocks and these firms grew considerably, owners of these firms could be classified as oligarchs and this would also lead to reverse causality. ${ }^{22}$ Note that since the

\footnotetext{
${ }^{20}$ Oligarchs are likely to overstate costs and understate sales thus reducing measured productivity. Formally, let us denote recorded sales with $\tilde{S}_{i}$ and measured productivity with $\tilde{a}_{i}$. Then the measured productivity is $\tilde{a}_{i}=\left(\tilde{S}_{i}-C_{i}\right) / C_{i}=\left(1-\delta_{i}^{*}\right)\left(1+a_{i}\right)-1$. It follows that as long as $\delta_{i}^{*}>0$ we should observe $0<\tilde{a}_{i}<a_{i}$. Because optimal looting $\delta_{i}^{*}$ is increasing in productivity, a genuinely productive firm owned by an oligarch may look unproductive even after a productivity enhancing investment. Hence, this estimate is likely to be a lower bound on the effect of oligarch ownership.

${ }^{21}$ See for example, "Alchevsk Steel Mill: A Year for Five" in Zerkalo Nedeli (\#42, 1999) and "The Conflict of Special Interest" in Zerkalo Nedeli (\#39, 2003).

${ }^{22}$ We believe that this source of endogeneity is quantitatively small in our case. First, we control for industry and region specific trends and firm specific time invariant effects. Thus $u_{i}$ absorbs only within (temporal) variation in productivity while assignment of oligarch status is based on long-run level of productivity, i.e., the between variation in the data. Given that between variation in our sample is at least 10 times larger than within variation, the possibility
} 
mechanics of this additional source of endogeneity is identical to "cherry picking" in the sense that positive $u_{i}$ causes $O L I G A R C H_{i}$, our instrumental variable framework addresses this additional source of endogeneity as well.

Nonetheless, the negative correlation is in agreement with our story. Consistent with disorganization literature (e.g., Blanchard and Kremer 1997), disintegration of production chains hit large firms the hardest (low $\varepsilon_{i}$ ), but the potential gains from investment/reintegration were the largest for these firms (large $u_{i}$ ). Furthermore, according to our model, oligarchs should want to have large and not necessarily productive firms. Indeed, the "size" motive in acquiring firms dominates the "productivity" motive in the estimated selection equation. Likewise, analysis of privatization and anecdotal evidence (see above) indicates that observed size should have been a more important dimension for acquisition than unobserved productivity. Large firms created in the Soviet time have been relatively unproductive in the early years of the market economy in Ukraine. Because large firms grew slower than small firms and because oligarchs own larger firms than other owners, firms owned by oligarchs seem to grow at about the same rate as firms in the control group according to OLS estimates. In other words, the composition of the firms is different in the treated and control group and this difference in the composition biases OLS down. Once oligarchs acquire large firms they have the incentive to enhance the productivity of those firms, which explains the negative correlation.

Of course, these results depend on whether the probability of being owned by an oligarch is a sufficiently strong instrument for actual ownership by an oligarch. To verify that the instrument is not weak, we consider the following diagnostic statistics. The first stage F-statistic is well above 20, the critical value suggested by Stock, Wright and Yogo (2002, Table 1, p. 522). Hence, it is unlikely that the instrument is weak. Alternatively, one can consider inference

of classifying an owner as an oligarch because of temporary shocks to productivity is not likely. Second, the relevant size in our oligarch classification is given by the size of the total property owned by a given person rather than the size of a single firm. Since oligarchs own very many firms (the order of magnitude is hundreds of firms), the relationship between lucky productivity draw in any given firm and this firm's owners being classified as oligarchs is small. In other words, we look at the size of an empire rather than a small building block of this empire. Finally, this source of endogeneity predicts a positive correlation between $\varepsilon_{i}$ in equation (6) and $u_{i}$ in equation (7). In contrast, we find a strong, statistically significant negative correlation which cannot be reconciled with this source of endogeneity. 
methods that are fully robust to weak instruments, e.g., the Anderson-Rubin (AR) statistic. We find that the AR statistic for the null hypothesis $\beta=0$ exceeds the $5 \%$ critical value computed as in Moreira (2003). Hence, the instrument is sufficiently strong and our conclusions are robust on this front as well.

Now we experiment with the selection equation (6) by augmenting the list of controls with investment-to-capital ratio, liquidity of output (share of sales actually paid) and higher moments of sales, capital and labor in 1993. We report the estimates of these augmented specifications in Table 5. Investment-to-capital ratio in 1993 is negatively associated with the oligarch ownership (column 2). Likewise, oligarchs are more likely to own firms that had liquidity problems in 1993 (column 3). These results are consistent with our story. In 1993, because of disorganization, would-be-owned-by-oligarchs firms had falling investment rates and liquidity problems. This allowed oligarchs to buy these firms cheaply. On the other hand, those firms tended to have a large potential surplus from investment or reintegration in a production chain. Inclusion of second-order terms in capital, labor and sales shows that the probability of being owned by an oligarch is convex in capital stock (column 4). Combination of these additional variables leads to similar conclusions (column 5). Using these alternative selection specifications, we re-estimate the treatment effect of oligarchs and present estimates in Table 6. Based on these alternative estimates, we reach the same qualitative conclusion: oligarchs seem to raise productivity of the firms they own significantly.

Finally, we estimate the treatment effect using non-parametric matching estimator of Abadie and Imbens (2002, 2006). In brief, the matching estimator finds an untreated firm as close to a treated firm as possible along specified characteristics (dimensions) and takes the average difference in outcomes across matched pairs as the treatment effect. Since matching should be based on variables not affected by the treatment, we use firm characteristics in 1993 to match firms owned by oligarchs to firms not owned by oligarchs. Specifically, the set of variables on which we match firms is the set of the right hand side variables in equation (6) (Baseline specification) and the same list augmented with the investment-to-capital ratio (Specification 1), 
with liquidity of output (Specification 2) and with combination of the investment-to-capital ratio and liquidity of output (Specification 3). The estimates of the treatment effect based on the matching estimator are presented in Table 7. The estimates are somewhat smaller than estimates in the IV and SEL estimators but the treatment effect estimate remains highly economically and statistically significant. In particular, firms owned by oligarchs tend to grow about $40-45 \%$ faster than firms not owned by oligarchs.

It is possible that our control group that comprises of foreign, state and privately owned firms is too crude and the difference between one of these forms of ownership and the oligarch ownership is less striking. Unfortunately, our sample has only a handful of firms with genuinely foreign ownership. Oligarchs and other domestic private owners often own firms via off-shores and thus firms that are foreign on paper have de facto domestic owners. Because the number of genuinely foreign firms is very small (slightly above 20), we could make a meaningful statistical distinction only between state and private ownership. Consistent with previous literature (e.g., Estrin and Rosevear (1999), Brown et al (2006)), we find that state ownership in Ukraine is associated with smaller productivity gains when compared to private ownership, but the difference is quite small. More importantly, the differences between private and state ownership are dwarfed when compared to the differences between oligarch and non-oligarch ownership. In our sample, state firms grew about $10 \%$ less than privately owned firms and this difference is marginally significant. At the same time, the difference between oligarch and non-oligarch ownership is 5 to 7 times larger than the difference between state and private non-oligarch ownership. Not surprisingly, when we include a dummy variable for state ownership in equation (7), point estimates of the oligarch treatment effect (now relative to private non-oligarch ownership) are very similar to the treatment effects we report in Tables 4 through 7 . Thus our conclusions are not driven by combining potentially heterogeneous state and private non-oligarch ownership into a single control group. 
The results survive in a number of other robustness checks. Modifications in specifications and samples lead to qualitatively the same conclusions. Therefore, oligarchs are indeed likely to improve productivity of the firms they own.

\section{CONCLUDING REMARKS}

The paper provides a theoretical model and an empirical test of the economic behavior of "oligarchs", the strong financial and industrial groups observed in many countries in Central and South-East Asia, Latin America, and Central-Eastern Europe.

Our theoretical model explains important stylized facts about the behavior of oligarchs. The model predicts that oligarchs are more likely than other owners to invest in productivity enhancing projects and to vertically integrate firms to capture the gains from possible synergies. We argue that the economic recovery in transition countries of the FSU can be linked to the formation of strong business groups restoring and reinvigorating production chains in those countries. In addition to the common sense wisdom of low taxes and high level of penalty for looting, the model suggests an important welfare-improving policy recommendation that the marginal penalty for looting should be elastic.

We test the implications of the model using a unique data set constructed from a number of firm-level databases. Our econometric results suggest that oligarchs are "good" at least in some dimensions. In particular, an average oligarch does appear to stimulate productivity ceteris paribus, that is, firms owned by oligarchs tend to have higher productivity growth than firms not owned by oligarchs. This result is compatible with Olson's "stationary bandit", i.e., even robber barons can be socially beneficial.

We are cautious enough, however, to not overemphasize this result. First, the overall impact of oligarchs' activity cannot be quantified with data at hand, and so we are not able to establish whether productivity gains offset lost tax revenue in reality. Second, the beneficial influence of financial industrial groups is likely to be much greater in the early stages of transition, when market forms of coordination are not well developed. As economy recovers and 
institutions develop, the alternative ways of preserving adequate level of productive investments become available to the society (via efficient capital markets, for example). For example, Acemoglu (2003) presents a model where oligarchic societies can dominate democracies in the short run but democracies dominate oligarchies in the long run. Generally speaking, our model suggests that oligarchs would be especially 'useful' to the society in heavily taxed and regulated economies (where looting naturally provides some limit to inefficiencies generated by tax distortions) or in hostile business environments (where returns to investment/integration are high). These are features usually attributed to transition countries and emerging markets rather than to developed Western economies. Third, oligarchs have consequences other than just promoting productive efficiency. In particular, oligarchs' activities inevitably lead to a concentration of the industry. For instance, Guriev and Rachinsky (2005) report that oligarchs in Russia have enormous control over the Russian economy. Therefore, oligarchs can exercise their monopolistic power thereby causing losses to the society. Normative issues such as the distribution of surplus should also be considered.

In the end, we hope that the reader finds that the phenomenon of oligarchs deserves careful consideration and this research can provide a starting point for this analysis. A detailed cost-benefit analysis is required to make a final judgment concerning the desirability of oligarchs at various stages of development and transition. In any case, the existence of oligarch/business groups is typical for all developed economies as well as developing and transition countries, and the ultimate utility of oligarch/business groups seems to be a matter of effectiveness of public control and other measures (e.g., openness of the economy) to restrain the power of these groups. 


\section{REFERENCES}

Abadie, Alberto, and Guido W. Imbens, 2002. "Simple and Bias-Corrected Matching Estimators for Average Treatment Effects," NBER Technical Working Paper.

Abadie, Alberto, and Guido W. Imbens, 2006. "Large Sample Properties of Matching Estimators for Average Treatment Effects," Econometrica 74(1), 235-268.

Acemoglu, Daron, 2003. "The Form of Property Rights: Oligarchic vs. Democratic Societies," NBER Working Paper.

Åslund, Anders, 2000. "Why has Ukraine failed to achieve economic growth?" in Economic Reform in Ukraine: The Unfinished Agenda (New York: M. E. Sharpe), Anders Aslund and Georges de Menil eds., pp. 255 -277.

Åslund, Anders, 2005. "Comparative Oligarchy: Russia, Ukraine and the United States," Center for Economic and Social Research, Working Paper 296.

Åslund, Anders, Peter Boone, and Simon Johnson, 2001. "Escaping the Under-Reform Trap," IMF Staff Papers 48, Special Issue.

Black, Bernard S. and Anna S. Tarassova, 2002. "Institutional Reform in Transition: A Case Study of Russia," Stanford Law School Working Paper.

Blanchard, Oliver and Michael Kremer, 1997. "Disorganization," Quarterly Journal of Economics 112, 1091-1126.

Bondarenko, Kost, 2000. Atlantes and Caryathides under the President's Roof, Lviv, Ukraine: Kalvaria.

Bondarenko, Kost, 2003. "Who Owns What in Ukraine," Ukrainian Pravda, July 17, 2003, Kiev, Ukraine.

Boone, Peter, and Denis Rodionov, 2002. "Rent seeking in Russia and the CIS," mimeo.

Braguinsky, Serguey, and Roger Myerson, 2007. "A macroeconomic model of Russian transition - The role of oligarchic property rights," Economics of Transition 15, 77-107.

Brown, David, John Earle and Amos Telegdy, 2006. "The productivity effects of privatization: Longitudinal estimates from Hungary, Romania, Russia, and Ukraine," Journal of Political Economy 114, 61-99.

Coase, Ronald, 1937. “The Nature of the Firm,” Economica 4, 386-405.

Coase, Ronald, 1960. "The Problem of Social Cost,” Journal of Law and Economics 3, 1-44.

Djankov, Simeon and Peter Murrell, 2002. "Enterprise Restructuring in Transition: A Quantitative Survey," Journal of Economic Literature 40, 739-792.

Estrin, Saul, and Adam Rosevear, 1999. "Enterprise performance and ownership: The case of Ukraine,” European Economic Review 43, 1125-1136.

Freeland, Chrystia, 2000. Sale of the Century: Russia's Wild Ride from Communism to Capitalism, New York: NY: Crown Business.

Frydman, Roman, Cheryl Gray, Marek Hessel, and Andrzej Rapaczynski, 1999. "When Does Privatization Work? The Impact of Private Ownership on Corporate Performance in Transition Economies," Quarterly Journal of Economics 114, 1153-1191.

Gaidar, Yegor, 1997. Anomalies of the Socialist Growth, Moscow, Russia: Eurasia [in Russian].

Goldman, M., 2004. "The Rule of Outlaws is Over!” Transition Newsletter 14/15, 23-25.

Gorodnichenko, Yuriy, 2007. "Using firm optimization to evaluate and estimate returns to scale," NBER Working Paper. 
Griliches, Zvi and Jerry A. Hausman, 1986. "Errors in Variables in Panel Data," Journal of Econometrics 30, 93-118.

Guriev, Sergei and Andrei Rachinsky, 2005. "The Role of Oligarchs in Russian Capitalism," Journal of Economic Perspectives 19, 131-150.

Hanousek, Jan, Evzen Kocenda, and Jan Svejnar, 2007. "Origin and Concentration - Corporate Ownership, Control and Performance in Firms after Privatization," Economics of Transition 15(1), 1-31.

Hart, Oliver D., 1995. Firms, Contracts, and Financial Structure, Oxford, United Kingdom: Clarendon Press.

Havrylyshyn, Oleh, 2006. Divergent paths in post-communist transformation. Palgrave Macmillan.

Heckman, James, 1978. "Dummy Endogenous Variables in a Simultaneous Equation System," Econometrica 46, 931-959.

Heckman, James, and Salvador Navarro-Lozano, 2004. "Using Matching, Instrumental, and Control Functions to Estimate Economic Choice Models," Review of Economics and Statistics 86, 30-57.

Hoffman, David E., 2003. The Oligarchs: Wealth and Power in the New Russia, New York, NY: Public Affairs.

Investgazeta, “Top 100,” 24 June 2003, Kiev, Ukraine.

Investgazeta, “Top 100,” 26 July 2004, Kiev, Ukraine.

Johnson, Simon, John McMillan, and Christopher Woodruff, 2002. "Property Rights and Finance," The American Economic Review 92, 1335-1356.

Johnson, Simon, Rafael La Porta, Florencio Lopez-de-Silanes and Andrei Shleifer, 2000. "Tunneling," American Economic Review 90, 22-27.

Khanna, Tarun, and Jan W. Rivkin, 2001. "Estimating the Performance Effects of Business Groups in Emerging Markets," Strategic Management Journal 22, 45-74.

Khanna, Tarun, and Yishay Yafeh, 2007. "Business groups in emerging markets: Paragons or parasites?" Journal of Economic Literature 45, 331-372.

Klebnikov, Paul. 2000. Godfather of the Kremlin: Boris Berezovsky and the Looting of Russia, New York, NY: Harcourt.

Klein B., R. Crawford, and A. Alchian, 1978. "Vertical Integration, Appropriable Rents, and the Competitive Contracting Process," Journal of Law and Economics 21, 297-326.

Konings, Jozef, and Patrick P. Walsh. 1999. "Disorganization in Transition Process: Firm Level Evidence from Ukraine," Economics of Transition 8, 29-46.

Kornai, Janos, 1992. The Socialist System: The Political Economy of Communism, Oxford, United Kingdom: Oxford University Press.

La Porta, Rafael, Florencio Loper-De-Silanes, and Andrei Shleifer, 1999. "Corporate Ownership Around the World," Journal of Finance 54, 471-517.

Maddala, G.S., 1983. Limited-dependent and Qualitative Variables in Econometrics, Cambridge, United Kingdom: Cambridge University Press

Marin, Dalia, and Monika Schnitzer, 2002. Contracts in Trade and Transition, Cambridge, MA: MIT Press.

Marin, Dalia, and Monika Schnitzer, 2005. "Disorganization and Financial Collapse," European Economic Review 49, 387-408. 
Marschak, J., and W.H. Andrews, 1944. "Random Simultaneous Equations and the Theory of Production," Econometrica 12, 143-205.

Morreira, Marcelo J., 2003. "A Conditional Likelihood Ratio Test for Structural Models," Econometrica 71, 1027-1048.

Olson, Mancur, 2000. Power and Prosperity: Outgrowing Communist and Capitalist Dictatorships, New York, NY: Basic Books.

Orlov, Alexander, 2002. "The Chaps from the Donetsk Group," Ukrainian Pravda, 16 December 2002, Kiev, Ukraine.

Pappe, Yakov, 2000. Oligarchs: Economic Chronicle 1992-2000, Moscow, Russia: New Economic School at the Moscow State University, 2000 [in Russian].

Perotti, Enrico and Stansilav Gelfer, 2001. "Red Barons or Robber Barons? Governance and Investment in Russian Financial-Industrial Groups," European Economic Review 45, 16011617.

Pissarides, Francesca, Miroslav Singer, and Jan Svejnar, 2003. "Objectives and Constraints of Entrepreneurs: Evidence from Small and Medium Size Enterprises in Russia and Bulgaria," Journal of Comparative Economics 31, 503-531.

Recanatini, Francesca, and Randi Ryterman, 2000. "Disorganisation or Self-Organization," FEEM Working Paper No.26.00.

Roland, Gerard, and Terrier Verdier, 1999. "Transition and the Output Fall," Economics of Transition 7, 1-28.

Samphantharak, Krislert, “Internal Capital Markets in Business Groups,” mimeo, 2003.

Shleifer, Andrei and Daniel Treisman, 2005. "A Normal Country: Russia after Communism," Journal of Economic Perspectives 19, 151-174.

Stiglitz, Joseph, 1999. "Wither Reforms? Ten Years of the Transition," ABCDE conference, Washington, DC: World Bank.

Stock, James H., Johnathan H. Wright, and Motohiro Yogo, 2002. "A Survey of Weak Instruments and Weak Identification in Generalized Methods of Movements," Journal of Business and Economic Statistics 20, 518-529.

Tybout, James R. and M. Daniel Westbrook, 1996. "Scale Economies as a Source of Efficiency Gains," in Mark J. Roberts and James R. Tybout, eds., Industrial Evolution in Developing Countries, Oxford, United Kingdom: Oxford University Press.

Vella, F. and M. Verbeek, 1999. "Estimating and Interpreting Models with Endogenous Treatment Effects," Journal of Business and Economic Statistics 17, 473-478.

Wooldridge, Jeffrey, 2002. Econometric Analysis of Cross Section and Panel Data, Cambridge, MA: MIT Press. 


\section{Appendix A: Proofs}

\section{Proof of Proposition 1.}

1. To keep $f\left(\delta^{*}-a_{i} /\left(1+a_{i}\right)\right)<\infty$, the optimal looting trivially satisfies $\delta^{*}<a_{i} /\left(1+a_{i}\right)$.

2. After taking derivative from (2) observe that $\frac{\partial \delta^{*}}{\partial a_{i}}=\frac{1}{\left(1+a_{i}\right)^{2}}+\frac{\tau C_{i}}{f^{\prime \prime}\left(\delta^{*}-a_{i} /\left(1+a_{i}\right)\right)}>0$ by assumptions imposed on the penalty function.

3. After taking derivative from (2) observe that $\frac{\partial \delta^{*}}{\partial S_{i}}=\frac{\tau}{f^{\prime \prime}\left(\delta^{*}-a_{i} /\left(1+a_{i}\right)\right)}>0$ by assumptions imposed on the penalty function.

4. After taking derivative from (4) observe that the larger the fee/penalty for looting firms, the less attractive looting is, i.e., $\partial \Delta_{i} / \partial \phi=-1<0$. The proof for $f$ follows by analogy.

5. After taking derivative from (4) observe that by the envelope theorem $\partial \Delta_{i} / \partial \tau=\delta^{*} S_{i}>0$.

\section{Proof of Proposition 2.}

1. Suppose that firm equity capital $K_{i}$ is proportional to sales $S_{i}: \kappa K_{i}=S_{i}$. Then return on capital (ROC) is

$$
\begin{aligned}
R O C & =\frac{\delta_{i}^{*} S_{i} \tau+(1-\tau) \frac{a_{i}}{1+a_{i}} S_{i}-f\left(\delta_{i}^{*}-a_{i} /\left(1+a_{i}\right)\right)-\phi}{K_{i}}= \\
& =\left[\kappa \delta_{i}^{*} \tau-\kappa \frac{f\left(\delta_{i}^{*}-a_{i} /\left(1+a_{i}\right)\right)+\phi}{S_{i}}\right]+\kappa(1-\tau) \frac{a_{i}}{1+a_{i}} .
\end{aligned}
$$

The second term in (A.1) is the ROC received by a transparent owner. As long as the first term is positive the oligarch is looting firms. By the envelope theorem, the derivative of the first term with respect to $S_{i}$ is $S_{i}^{-2}\left[f\left(\delta_{i}^{*}-a_{i} /\left(1+a_{i}\right)\right)+\phi\right]>0$. Hence, the oligarch's ROC is increasing in the firm size. In contrast, the firm size is irrelevant for the ROC of a transparent owner.

2. Both the oligarch and the transparent owner have ROC increasing in $a_{i}$ through the second term in (A.1). By the envelope theorem, the derivative of the first term in (A.1) with respect to $a_{i}$ is

$$
\frac{\kappa \phi}{\left(1+a_{i}\right)^{2} C_{i}}+\kappa \frac{f^{\prime}\left(\delta_{i}^{*}-a_{i} /\left(1+a_{i}\right)\right)+\left(1+a_{i}\right) f\left(\delta_{i}^{*}-a_{i} /\left(1+a_{i}\right)\right)}{\left(1+a_{i}\right)^{3} C_{i}}>0 .
$$

Hence, the first term in (A.1) is increasing in productivity $a_{i}$. It follows that the oligarch's return is weakly larger than the ROC of the transparent owner.

\section{Proof of Proposition 3.}

To simplify notation, we suppress firm index $i$. Suppose in the no-investment case, the oligarch chooses to loot the firm. His benefit function under no-investment case is 
$B_{1}^{*}=\delta_{1}^{*}\left(1+a_{1}\right) C+(1-\tau)\left[\left(1-\delta_{1}^{*}\right)\left(1+a_{1}\right)-1\right] C-f\left(\delta_{1}^{*}-a_{1} /\left(1+a_{1}\right)\right)-1_{\delta>0} \phi$,

where $\delta_{1}^{*}=\delta^{*}\left(a_{1}\right)$. With investment the benefit is

$$
B_{2}^{*}=\delta_{2}^{*}\left(1+a_{2}\right) C+(1-\tau)\left[\left(1-\delta_{2}^{*}\right)\left(1+a_{2}\right)-1\right] C-f\left(\delta_{2}^{*}-a_{2} /\left(1+a_{2}\right)\right)-1_{\delta>0} \phi-\chi C,
$$

where $\delta_{2}^{*}=\delta^{*}\left(a_{2}\right)$. After subtracting optimized (A.2) from (A.3) and using the definition for $\Delta$ in (4), we have:

$$
\begin{aligned}
B_{2}^{*}-B_{1}^{*}= & {\left[(1-\tau)\left(a_{2}-a_{1}\right)-\chi\right] C+} \\
& +\tau C\left[\delta_{2}^{*}\left(1+a_{2}\right)-\delta_{1}^{*}\left(1+a_{1}\right)\right]+f\left(\delta_{1}^{*}-a_{1} /\left(1+a_{1}\right)\right)-f\left(\delta_{2}^{*}-a_{2} /\left(1+a_{2}\right)\right)= \\
= & {\left[(1-\tau)\left(a_{2}-a_{1}\right)-\chi\right] C+\left[\Delta_{2}-\Delta_{1}\right] . }
\end{aligned}
$$

The first term in (A.4) is the change in after-tax profit of the transparent owner who makes the investment if $(1-\tau)\left(a_{2}-a_{1}\right)-\chi>0$. The second term is specific to the looting oligarch. Note that by the envelope theorem (4)

$$
\partial \Delta / \partial a=\tau \delta^{*} C+(1+a)^{-2} f^{\prime}\left(\delta^{*}-a_{i} /\left(1+a_{i}\right)\right)>0 .
$$

Hence, the second term is always positive. If the transparent owner makes the investment, the oligarch also makes the investment. There are combinations of $a_{1}, a_{2}, \chi$ (e.g., $\left.a_{1}, a_{2}, \chi: a_{2}=a_{1}+(1-\tau)^{-1} \chi\right)$ such that the oligarch makes the investment when the transparent owner does not.

\section{Proof of Proposition 4.}

The looting oligarch pays $T_{i}=\tau\left[\left(1-\delta_{i}^{*}\right)\left(1+a_{i}\right)-1\right] C$ in taxes while the transparent owner pays $T_{i}=\tau a_{i} C$. Observe that the integrating oligarch pays more in taxes than the non-integrating transparent owner if and only if $\left(1-\delta_{2}^{*}\right)\left(1+a_{2}\right)-1 \geq a_{1}>\left(1-\delta_{1}^{*}\right)\left(1+a_{1}\right)-1$. Hence it is sufficient to show that $\left(1-\delta_{i}\right)\left(1+a_{i}\right)$ is increasing in $a_{i}$. Using results from Proposition 1, observe that

$$
\begin{aligned}
\frac{\partial}{\partial a}(1- & \left.\delta_{i}^{*}\right)\left(1+a_{i}\right)=\left(1-\delta_{i}^{*}\right)-\left(1+a_{i}\right) \frac{\partial \delta_{i}^{*}}{\partial a_{i}} \\
& \left.=\left(1-\delta_{i}^{*}\right)-\left(1+a_{i}\right)^{-1}-\left(1+a_{i}\right) \tau C_{i} / f^{\prime \prime}\left(\delta_{i}^{*}-a_{i} /\left(1+a_{i}\right)\right) \text { (use the FOC for } \delta_{i}^{*}\right) \\
& =-\left(\delta_{i}^{*}-a_{i} /\left(1+a_{i}\right)\right)-\frac{f^{\prime}\left(\delta_{i}^{*}-a_{i} /\left(1+a_{i}\right)\right)}{f^{\prime \prime}\left(\delta_{i}^{*}-a_{i} /\left(1+a_{i}\right)\right)} \\
& =-\left(\delta_{i}^{*}-a_{i} /\left(1+a_{i}\right)\right)\left(1+\varepsilon^{-1}\right) .
\end{aligned}
$$

where $\varepsilon=\left(\delta_{i}^{*}-a_{i} /\left(1+a_{i}\right)\right) \frac{f^{\prime \prime}\left(\delta_{i}^{*}-a_{i} /\left(1+a_{i}\right)\right)}{f^{\prime}\left(\delta_{i}^{*}-a_{i} /\left(1+a_{i}\right)\right)}$ is the elasticity of the marginal penalty for looting. Note that by Proposition 1.1, $-\left(\delta_{i}^{*}-a_{i} /\left(1+a_{i}\right)\right)>0$. Hence, $\partial T_{i} / \partial a_{i}>0$ if and only if $\varepsilon<-1$, that is, the marginal penalty is elastic. 
Now provided that $\frac{\partial}{\partial a_{i}}\left(1-\delta_{i}^{*}\right)\left(1+a_{i}\right)$ is positive and bounded away from zero, for a sufficiently large $a_{2}$ we will have $\left(1-\delta_{2}^{*}\right)\left(1+a_{2}\right)-1>a_{1}$ and, thus, the looting and investing oligarch will generate higher tax revenues than the transparent non-investing owner.

\section{Proof of Proposition 5.}

1) Note that in the case of the transparent owner the change in the profit is equal to

$$
\begin{aligned}
\Delta^{L} & =\pi_{I}-\pi_{D}-\pi_{U}-\chi C_{U}= \\
& =(1-\tau) a_{I} C_{U}-(1-\tau) a_{D}\left(1+a_{U}\right) C_{U}-(1-\tau) a_{U} C_{U}-\chi C_{U}= \\
& =C_{U}\left[(1-\tau)\left(a_{I}-a_{U}-a_{D}-a_{D} a_{U}\right)-\chi\right] .
\end{aligned}
$$

In the case of the oligarch, the change in the benefit is equal to

$$
\begin{aligned}
\Delta^{O}=B_{I} & -B_{D}-B_{U}-\chi C_{U}= \\
=C_{U} & {\left[(1-\tau)\left(a_{I}-a_{U}-a_{D}-a_{D} a_{U}\right)-\chi\right]+} \\
& +\left[\phi+f\left(\delta_{D}^{*}-a_{D} /\left(1+a_{D}\right)\right)+f\left(\delta_{U}^{*}-a_{U} /\left(1+a_{U}\right)\right)-f\left(\delta_{I}^{*}-a_{I} /\left(1+a_{i}\right)\right)\right]+ \\
& +\tau C_{U}\left[\delta_{I}^{*}\left(1+a_{I}\right)-\delta_{U}^{*}\left(1+a_{U}\right)-\delta_{D}^{*}\left(1+a_{D}\right)\left(1+a_{U}\right)\right] .
\end{aligned}
$$

Hence,

$$
\begin{aligned}
\Delta^{O}-\Delta^{L} & =\left[\phi+f\left(\delta_{D}^{*}-a_{D} /\left(1+a_{D}\right)\right)+f\left(\delta_{U}^{*}-a_{U} /\left(1+a_{U}\right)\right)-f\left(\delta_{I}^{*}-a_{I} /\left(1+a_{I}\right)\right)\right]+ \\
+ & \tau C_{U}\left[\delta_{I}^{*}\left(1+a_{I}\right)-\delta_{U}^{*}\left(1+a_{U}\right)-\delta_{D}^{*}\left(1+a_{D}\right)\left(1+a_{U}\right)\right] .
\end{aligned}
$$

We first prove that this expression is positive for the case when $a_{I^{\prime}}=a_{U}+a_{D}+a_{D} a_{U}$ and then show that this expression is increasing in $a_{i}$. Note that by (2) we have $\delta_{I^{\prime}}^{*}-a_{I^{\prime}} /\left(1+a_{I^{\prime}}\right)=f^{\prime-1}\left(\tau S_{I^{\prime}}\right)=f^{\prime-1}\left(\tau S_{D}\right)=\delta_{D}^{*}-a_{D} /\left(1+a_{D}\right)$. Thus the first expression is necessarily positive. To prove that the second term is positive, note that $\delta_{I^{\prime}}^{*}=\delta_{D}^{*}+a_{I^{\prime}} /\left(1+a_{I^{\prime}}\right)-a_{D} /\left(1+a_{D}\right)$ and $\delta_{U}^{*}<a_{U} /\left(1+a_{U}\right)$ and, thus,

$$
\begin{aligned}
\delta_{I^{\prime}}^{*}\left(1+a_{I^{\prime}}\right)-\delta_{U}^{*}\left(1+a_{U}\right)-\delta_{D}^{*}\left(1+a_{D}\right)\left(1+a_{U}\right)= \\
=\left(\delta_{D}^{*}+\frac{a_{I^{\prime}}}{1+a_{I^{\prime}}}-\frac{a_{D}}{1+a_{D}}\right)\left(1+a_{D}\right)\left(1+a_{U}\right)-\delta_{U}^{*}\left(1+a_{U}\right)-\delta_{D}^{*}\left(1+a_{D}\right)\left(1+a_{U}\right)> \\
\quad>\left(\frac{a_{I^{\prime}}}{1+a_{I^{\prime}}}-\frac{a_{D}}{1+a_{D}}\right)\left(1+a_{D}\right)\left(1+a_{U}\right)-\frac{a_{U}}{1+a_{U}}\left(1+a_{U}\right)= \\
=\frac{1}{\left(1+a_{D}\right)\left(1+a_{U}\right)+1}>0 .
\end{aligned}
$$


We conclude that $\Delta^{O}-\Delta^{L}>0$ for $a_{I^{\prime}}=a_{U}+a_{D}+a_{D} a_{U}$. By the envelope theorem, we have $\frac{\partial}{\partial a_{I}}\left\{\Delta^{O}-\Delta^{L}\right\}=\frac{\partial}{\partial a_{I}}\left\{\tau \delta_{I}^{*}\left(1+a_{I}\right) C_{U}-f\left(\delta_{I}^{*}-a_{I} /\left(1+a_{I}\right)\right)\right\}>0$. Hence, $\Delta^{O}-\Delta^{L}>0$ for $a_{I}>a_{I^{\prime}}$ and, thus, the oligarch has greater incentives to integrate firms.

2) The change in the tax revenues is

$$
\begin{aligned}
\Delta T & =\tau C_{U}\left[\left(1-\delta_{I}^{*}\right)\left(1+a_{I}\right)-1\right]-\tau C_{U}\left[\left(1-\delta_{U}^{*}\right)\left(1+a_{U}\right)-1\right]-\tau C_{U}\left[\left(1-\delta_{D}^{*}\right)\left(1+a_{D}\right)-1\right]\left(1+a_{U}\right)= \\
& =\tau C_{U}\left[\left(1-\delta_{I}^{*}\right)\left(1+a_{I}\right)-\left(1-\delta_{D}^{*}\right)\left(1+a_{D}\right)\right]+\tau C_{U}\left[\delta_{U}^{*}\left(1+a_{U}\right)-\left(1-\delta_{D}^{*}\right)\left(1+a_{D}\right) a_{U}\right] .
\end{aligned}
$$

From Proposition 4, we know that the necessary and sufficient condition for the first term to be positive is the elastic marginal penalty for looting. The second term is always negative because

$$
\begin{gathered}
\delta_{U}^{*}\left(1+a_{U}\right)-\left(1-\delta_{D}^{*}\right)\left(1+a_{D}\right) a_{U}=\delta_{U}^{*}\left(1+a_{U}\right)+\delta_{D}^{*} a_{U}\left(1+a_{D}\right)-\left(1+a_{D}\right) a_{U}< \\
<\frac{a_{U}}{1+a_{U}}\left(1+a_{U}\right)+\frac{a_{D}}{1+a_{D}} a_{U}\left(1+a_{D}\right)-\left(1+a_{D}\right) a_{U}=0 .
\end{gathered}
$$

where we use $\delta_{i}^{*}<a_{i} /\left(1+a_{i}\right)$ (see Proposition 1). Hence, the elastic marginal penalty is the necessary condition for the "oligarch" integration to generate larger tax revenues so that for a sufficiently large gain in productivity the integrating oligarch pays more in taxes than the noninvesting transparent owner. 


\section{APPENDIX B: OLIGARCHS AND EFFICIENCY}

Following Hart's (1995), we assume that downstream firm can make revenue increasing investment $i$ and upstream firm can make cost enhancing investment $e$. We use subscripts $I, D$, and $U$ to denote an ideal (i.e., when parties have access to each other's human and physical capital), downstream agent and upstream agent cases. In addition to our standard set of assumptions, suppose that investments are observable by an owner but not verifiable. In such circumstances, the owner is able to decide on maximum investment budget for each of the firms but delegates the investment picking to an agent. Further, assume that an agent's compensation is directly proportional to total profits of the firm he manages, so that he is motivated to maximize the latter when picking investment projects. Our set of assumptions should also include those of the basic Hart model: the sales of downstream firm $S_{I}(i), S_{D}(i), S_{U}(i)$ and cost of upstream firm $C_{I}(e), \quad C_{D}(e), \quad C_{U}(e)$ are well-behaved-i.e., $\quad S_{k}(i) \in C^{2}, \partial S_{k}(i) / \partial i>0, \partial^{2} S_{k}(i) / \partial i^{2}<0 \quad$ and $C_{k}(e) \in C^{2}, \partial C_{k}(e) / \partial e<0, \partial^{2} C_{k}(e) / \partial e^{2}>0$ for $k=U, D, I$ - and ideal integration dominates other forms of integration, i.e.,

$$
\begin{array}{ll}
S_{I}(i)>\max \left\{S_{D}(i), S_{U}(i)\right\}, \partial S_{I}(i) / \partial i>\max \left\{\partial S_{D}(i) / \partial i, \partial S_{U}(i) / \partial i\right\} & \forall i \\
C_{I}(e)<\min \left\{C_{D}(e), C_{U}(e)\right\}, \partial C_{I}(e) / \partial e<\max \left\{\partial C_{D}(e) / \partial e, \partial C_{U}(e) / \partial e\right\} & \forall e .
\end{array}
$$

Obviously, upstream and downstream firms can make at most a profit of

$$
\pi_{I}=\max _{i, e}\left\{S_{I}(i)-C_{I}(e)-i-e\right\}
$$

The first order condition for (A.6) with respect to $i$ and $e$ gives:

$$
\begin{aligned}
& \partial S_{I}(i) / \partial i-1=0 \\
& \partial C_{I}(e) / \partial e+1=0
\end{aligned}
$$

Hart (1995) shows that levels of investment determined by (A.7) and (A.8) are not attainable because under any form of ownership agents do not have full access to and control over human and physical capital of other members of the group, e.g. the upstream firm does not enjoy full control over all assets of the downstream firm. Hence, upstream or downstream integration results 
in suboptimal levels of investment and by monotonicity of cost and revenue functions we, therefore, have at the respective optimal investments

$$
\begin{aligned}
& \partial S_{D}(i) / \partial i<\partial S_{I}(i) / \partial i \leq 1 \quad \forall i, \\
& \partial C_{D}(e) / \partial e>\partial C_{I}(e) / \partial e \geq-1 \quad \forall e .
\end{aligned}
$$

Now let us turn to the analysis of revenue increasing investment and the behavior of the downstream firm. The oligarch's revenue in tax havens is $\delta_{D}(i) S_{D}(i)$. The downstream firm faces the following profit function: $\pi_{I}^{D}=\left(1-\delta_{D}(i)\right) \cdot S_{D}(i)-C_{D}-i-f\left(\delta_{D}(i)-a_{D} /\left(1+a_{D}\right)\right)-\phi$. The first order condition with respect to $i$ yields:

$$
-\frac{\partial S_{D}(i) \cdot \delta_{D}(i)}{\partial i}-\frac{\partial f}{\partial \delta} \cdot \frac{\partial \delta_{D}}{\partial i}=1-\frac{\partial S_{D}(i)}{\partial i}
$$

The first term in the left hand side of (A.11) is the oligarch's marginal gain in looting revenue from investment (the optimizing oligarch can operate only on a range of $i$ such that $\delta_{D}(i) S_{D}(i)$ is increasing in $i$ ); thus, this term is always non-negative. By assumptions of the problem and (A.9), the right hand side is always non-negative. We also know that $\partial f / \partial \delta>0$ by assumptions imposed on the penalty function $f$. Hence, $\partial \delta_{D}(i) / \partial i$ must be less than zero to have an interior well-defined solution to profit maximization problem. Denote the solution to (A.7) with $i^{*}$. Provided $\partial \delta_{D}(i) / \partial i<0$ and $\delta_{D}\left(i^{*}\right) \in\left[0, a\left(i^{*}\right) /\left(1+a\left(i^{*}\right)\right)\right)$, the oligarch, by choosing appropriate functional form for $\delta_{D}(i)$, can induce the downstream firm to make the first best level of investment $i^{*}$. Thus, the oligarch can achieve an outcome that is not attainable under either upstream or downstream integration. By the symmetry of the problem, the same results can be shown for cost enhancing investment and the upstream firm. We conclude that the oligarch achieve superior outcomes in the Hart setup. 
Table 1. Distribution of the oligarch ownership by oligarchic groups and industries, 2002.

\begin{tabular}{|c|c|c|c|c|c|c|c|}
\hline Oligarchic group & Energy & Metal & Chemical & $\begin{array}{l}\text { Machine } \\
\text { building }\end{array}$ & $\begin{array}{l}\text { Light and } \\
\text { food }\end{array}$ & Service & Total \\
\hline Industrial Union of Donbass (Taruta-Mkrtchan) & 0 & 7 & 0 & 9 & 0 & 0 & 16 \\
\hline InterProduct (Leschinskiy) & 1 & 0 & 0 & 2 & 13 & 0 & 16 \\
\hline System Capital Management (Akhmetov) & 6 & 16 & 6 & 49 & 40 & 1 & 118 \\
\hline Dynamo (Surkis-Medvedchuk) & 3 & 2 & 1 & 3 & 3 & 0 & 12 \\
\hline Pryvat (Kolomoyskiy) & 1 & 9 & 2 & 5 & 1 & 2 & 20 \\
\hline Bipe (Pinchuk) & 0 & 4 & 0 & 2 & 5 & 0 & 11 \\
\hline InterContact (Yedin) & 1 & 0 & 0 & 4 & 2 & 0 & 7 \\
\hline PromInvest (Poroshenko) & 2 & 0 & 0 & 5 & 5 & 0 & 12 \\
\hline Aval (Shpyg) & 1 & 0 & 0 & 9 & 9 & 1 & 20 \\
\hline UkrSotsBank (Khoroshkovskiy) & 0 & 0 & 0 & 2 & 1 & 0 & 3 \\
\hline Brinkford/Orlan (Zhvania/Chervonenko) & 0 & 0 & 0 & 2 & 0 & 0 & 2 \\
\hline UkrSibBank (Yaroslavskiy) & 0 & 2 & 3 & 13 & 8 & 1 & 27 \\
\hline Finance\&Credit (Kucherenko) & 0 & 0 & 2 & 9 & 1 & 0 & 12 \\
\hline Total & 15 & 40 & 14 & 114 & 88 & 5 & 276 \\
\hline
\end{tabular}

Note: The table reports the number of firms that belong to an oligarchic group in a given industry in our sample. Names of the corporate characters are in the parentheses. 
Table 2. Descriptive statistics.

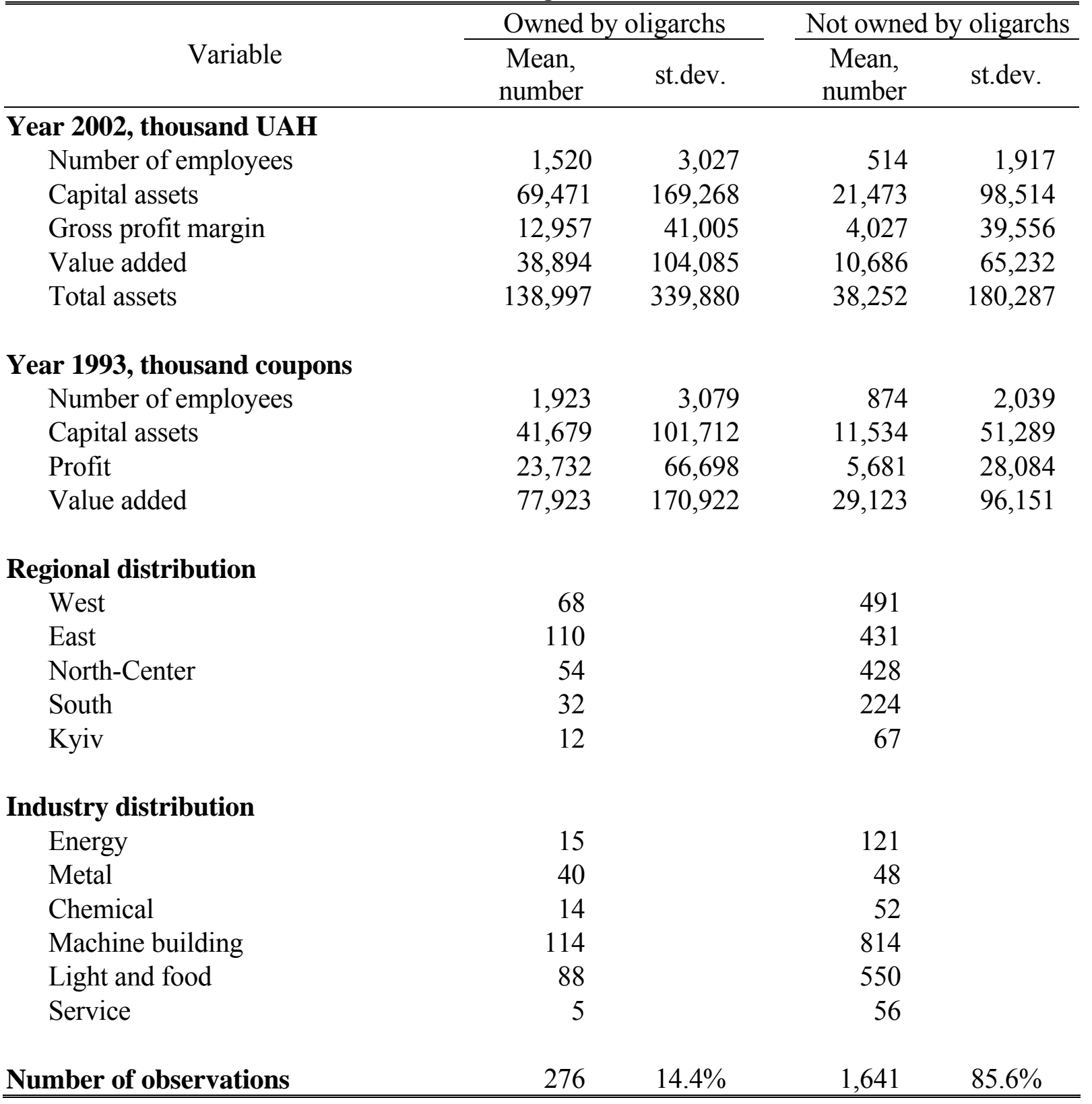

Note: ownership criteria are described in the text. 
Table 3. First stage/Selection equation. Probit estimates.

\begin{tabular}{|c|c|}
\hline regressor & Oligarch dummy \\
\hline (1) & $(2)$ \\
\hline $\log \left(\right.$ Capital $\left.^{(93)}\right)$ & $\begin{array}{l}0.115 * * \\
(0.048)\end{array}$ \\
\hline $\log \left(\right.$ Sales $\left.^{(93)}\right)$ & $\begin{array}{l}0.162 * * * \\
(0.042)\end{array}$ \\
\hline $\log \left(\right.$ Labor $\left.^{(93)}\right)$ & $\begin{array}{l}-0.073 \\
(0.057)\end{array}$ \\
\hline East & $\begin{array}{c}0.161 \\
(0.101)\end{array}$ \\
\hline South & $\begin{array}{l}-0.034 \\
(0.119)\end{array}$ \\
\hline North-Center & $\begin{array}{l}-0.086 \\
(0.100)\end{array}$ \\
\hline Kyiv & $\begin{array}{c}0.097 \\
(0.183)\end{array}$ \\
\hline Metals & $\begin{array}{l}0.996^{* * * *} \\
(0.193)\end{array}$ \\
\hline Chemical & $\begin{array}{l}0.616^{* * * *} \\
(0.227)\end{array}$ \\
\hline Machine building & $\begin{array}{l}0.533^{* * * *} \\
(0.158)\end{array}$ \\
\hline Light\&food & $\begin{array}{l}0.655^{* * * *} \\
(0.178)\end{array}$ \\
\hline Services & $\begin{array}{c}0.369 \\
(0.262) \\
\end{array}$ \\
\hline Observations & 1917 \\
\hline $\operatorname{LR} \chi^{2}$ & 135.10 \\
\hline Pseudo-R ${ }^{2}$ & 0.088 \\
\hline
\end{tabular}

Note: The table presents estimates of specification (6). Dependent variable is the OLIGARCH dummy, which is one if an oligarch owns a firm and zero otherwise. Robust standard errors are in parentheses. Omitted industry is energy. Omitted region is west. Definitions of the variables are in the text. $*, * *, * *$ significant at $10 \%, 5 \%$, and $1 \%$ respectively. 
Table 4. Production function.

\begin{tabular}{|c|c|c|c|}
\hline Regressor & OLS & IV & SEL \\
\hline$(1)$ & $(2)$ & (3) & (4) \\
\hline \multirow[t]{2}{*}{ OLIGARCH } & 0.078 & $0.638 * *$ & $0.691 * * *$ \\
\hline & $(0.068)$ & $(0.276)$ & $(0.181)$ \\
\hline \multirow[t]{2}{*}{$\Delta \log ($ Capital $)$} & $0.090 * * *$ & $0.084 * *$ & $0.097 * * *$ \\
\hline & $(0.035)$ & $(0.036)$ & $(0.036)$ \\
\hline \multirow[t]{2}{*}{$\Delta \log ($ Labor $)$} & $1.193 * * *$ & $1.180 * * *$ & $1.189 * * *$ \\
\hline & $(0.027)$ & $(0.036)$ & $(0.035)$ \\
\hline \multirow[t]{2}{*}{ Metal } & $0.504 * * *$ & $0.312 * *$ & $0.295 * *$ \\
\hline & $(0.141)$ & $(0.159)$ & $(0.141)$ \\
\hline \multirow[t]{2}{*}{ Chemical } & $0.279 *$ & 0.213 & 0.217 \\
\hline & $(0.154)$ & $(0.177)$ & $(0.174)$ \\
\hline \multirow[t]{2}{*}{ Machine building } & $0.286 * * *$ & $0.268 * *$ & $0.278 * * *$ \\
\hline & $(0.095)$ & $(0.107)$ & $(0.106)$ \\
\hline \multirow[t]{2}{*}{ Light\&food } & $0.231 * *$ & $0.215 * *$ & $0.213 * *$ \\
\hline & $(0.096)$ & $(0.109)$ & $(0.108)$ \\
\hline \multirow[t]{2}{*}{ Service } & $0.909 * * *$ & $0.915 * * *$ & $0.922 * * *$ \\
\hline & $(0.158)$ & $(0.191)$ & $(0.191)$ \\
\hline \multirow[t]{2}{*}{ Kyiv } & $0.545 * * *$ & $0.534 * * *$ & $0.533 * * *$ \\
\hline & $(0.117)$ & $(0.126)$ & $(0.126)$ \\
\hline $\mathrm{R}^{2}$ & 0.58 & 0.57 & \\
\hline First stage F-statistic & & 73.95 & \\
\hline AR statistic & & 4.83 & \\
\hline Hausman test: $p$-value & & 0.02 & \\
\hline$\rho\left(\varepsilon_{i}, u_{i}\right)$ & & & $-0.339 * * *$ \\
\hline Wald $\chi^{2}$ & & & 1984.64 \\
\hline $\log L^{n}$ & & & -3571.32 \\
\hline
\end{tabular}

Note: The table presents estimates of specification (7). Dependent variable is the change in log value added between 1993 and 2002. IV, SEL, MATCH are instrumental variables, selection-corrected treatment effects, and nearest-neighbor matching estimators, respectively. Robust standard errors are in parentheses. Omitted industry is energy. Definitions of the variables are in the text. $* * *, * * *$ significant at $10 \%, 5 \%$, and $1 \%$ respectively. AR is the Anderson-Rubin statistic with critical values computed as in Moreira (2003). Critical value for the AR statistic are 3.84 and 5.41 for $5 \%$ and $1 \%$, respectively (500 simulations). Number of observations is 1,917 . 
Table 5. Alternative selection specifications

\begin{tabular}{|c|c|c|c|c|}
\hline \multirow{2}{*}{ regressors } & \multicolumn{4}{|c|}{ Oligarch dummy } \\
\hline & Specification 1 & Specification 2 & Specification 3 & Specification 4 \\
\hline$(1)$ & $(2)$ & $(3)$ & (4) & $(5)$ \\
\hline \multirow[t]{2}{*}{$\log \left(\right.$ Capital $\left.^{(93)}\right)$} & $0.092 *$ & $0.084 *$ & $-0.418 * *$ & $-0.608 * *$ \\
\hline & $(0.050)$ & $(0.048)$ & $(0.209)$ & $(0.242)$ \\
\hline \multirow[t]{2}{*}{$\log \left(\right.$ Sales $\left.^{(93)}\right)$} & $0.180 * * *$ & $0.198 * * *$ & -0.005 & 0.151 \\
\hline & $(0.044)$ & $(0.042)$ & $(0.221)$ & $(0.255)$ \\
\hline \multirow[t]{2}{*}{$\log \left(\right.$ Labor $\left.^{(93)}\right)$} & -0.068 & -0.071 & 0.311 & 0.325 \\
\hline & $(0.057)$ & $(0.056)$ & $(0.277)$ & $(0.288)$ \\
\hline \multirow[t]{2}{*}{ East } & 0.161 & $0.182 *$ & 0.156 & $0.173 *$ \\
\hline & $(0.101)$ & $(0.103)$ & $(0.101)$ & $(0.103)$ \\
\hline \multirow[t]{2}{*}{ South } & -0.039 & 0.000 & -0.034 & -0.012 \\
\hline & $(0.119)$ & $(0.123)$ & $(0.118)$ & $(0.121)$ \\
\hline \multirow[t]{2}{*}{ North-Center } & -0.080 & -0.080 & -0.083 & -0.075 \\
\hline & $(0.101)$ & $(0.104)$ & $(0.100)$ & $(0.104)$ \\
\hline \multirow[t]{2}{*}{ Kyiv } & 0.098 & 0.013 & 0.126 & 0.050 \\
\hline & $(0.184)$ & $(0.199)$ & $(0.183)$ & $(0.200)$ \\
\hline \multirow[t]{2}{*}{ Metals } & $0.976 * * *$ & $1.253 * * *$ & $0.963 * * *$ & $1.191 * * *$ \\
\hline & $(0.194)$ & $(0.214)$ & $(0.208)$ & $(0.229)$ \\
\hline \multirow[t]{2}{*}{ Chemical } & $0.593 * * *$ & $0.908 * * *$ & $0.637 * * *$ & $0.913 * * *$ \\
\hline & $(0.226)$ & $(0.239)$ & $(0.235)$ & $(0.248)$ \\
\hline \multirow[t]{2}{*}{ Machine building } & $0.504 * * *$ & $0.755 * * *$ & $0.623 * * *$ & $0.831 * * *$ \\
\hline & $(0.159)$ & $(0.168)$ & $(0.169)$ & $(0.178)$ \\
\hline \multirow[t]{2}{*}{ Light\&food } & $0.635 * * *$ & $0.834 * * *$ & $0.723 * * *$ & $0.891 * * *$ \\
\hline & $(0.177)$ & $(0.194)$ & $(0.186)$ & $(0.202)$ \\
\hline \multirow[t]{2}{*}{ Services } & 0.323 & $0.620 * *$ & $0.452 *$ & $0.661 * *$ \\
\hline & $(0.263)$ & $(0.275)$ & $(0.269)$ & $(0.285)$ \\
\hline \multirow[t]{2}{*}{ Invest $^{(93)} /$ Capital $^{(93)}$} & $-0.767 * *$ & & & $-0.997 * * *$ \\
\hline & $(0.360)$ & & & $(0.369)$ \\
\hline \multirow[t]{2}{*}{ Liquidity $^{(93)}$} & & $-0.801 * * *$ & & $-0.760 * * *$ \\
\hline & & $(0.215)$ & & $(0.215)$ \\
\hline \multirow[t]{2}{*}[\operatorname{Log}(\operatorname{Capital}^{(93)})]{$^{2}$} & & & $0.032 * *$ & $0.041 * * *$ \\
\hline & & & $(0.013)$ & $(0.015)$ \\
\hline \multirow[t]{2}{*}[\operatorname{Log}(\text{Sales}^{(93)})]{$^{2}$} & & & 0.009 & 0.003 \\
\hline & & & $(0.012)$ & $(0.014)$ \\
\hline \multirow[t]{2}{*}[\operatorname{Log}(\operatorname{Labor}^{(93)})]{$^{2}$} & & & -0.032 & -0.033 \\
\hline & & & $(0.022)$ & $(0.023)$ \\
\hline $\operatorname{LR} \chi^{2}$ & 135.95 & 154.19 & 141.48 & 166.55 \\
\hline Pseudo-R ${ }^{2}$ & 0.089 & 0.100 & 0.093 & 0.110 \\
\hline
\end{tabular}

Note: The table presents estimates of specifications analogous to (6). Dependent variable is the OLIGARCH dummy, which is one if an oligarch owns a firm and zero otherwise. Robust standard errors are in parentheses. Omitted industry is energy. Omitted region is west. Definitions of the variables are in the text. *,**, *** significant at $10 \%, 5 \%$, and $1 \%$ respectively. Number of observations is 1,917 . 
Table 6. Alternative estimates of the treatment effect

\begin{tabular}{|c|c|c|c|c|c|c|c|c|}
\hline \multirow{2}{*}{ Regressor } & \multicolumn{2}{|c|}{ Specification 1} & \multicolumn{2}{|c|}{ Specification 2} & \multicolumn{2}{|c|}{ Specification 3} & \multicolumn{2}{|c|}{ Specification 4} \\
\hline & IV & SEL & IV & SEL & IV & SEL & IV & SEL \\
\hline$(1)$ & $(2)$ & $(3)$ & $(4)$ & $(5)$ & (6) & $(7)$ & $(8)$ & (9) \\
\hline OLIGARCH & $\begin{array}{c}0.654 * * \\
(0.275)\end{array}$ & $\begin{array}{l}0.742 * * * \\
(0.184)\end{array}$ & $\begin{array}{l}0.748 * * * \\
(0.268)\end{array}$ & $\begin{array}{l}0.790 * * * \\
(0.183)\end{array}$ & $\begin{array}{c}0.553 * * \\
(0.263)\end{array}$ & $\begin{array}{l}0.661 * * * \\
(0.186)\end{array}$ & $\begin{array}{l}0.628 * * \\
(0.248)\end{array}$ & $\begin{array}{l}0.783 * * * \\
(0.191)\end{array}$ \\
\hline$\Delta \log ($ Capital $)$ & $\begin{array}{c}0.075^{*} \\
(0.038)\end{array}$ & $\begin{array}{l}0.091^{* *} \\
(0.037)\end{array}$ & $\begin{array}{l}0.082 * * \\
(0.037)\end{array}$ & $\begin{array}{l}0.095 * * * \\
(0.036)\end{array}$ & $\begin{array}{l}0.088 * * \\
(0.037)\end{array}$ & $\begin{array}{l}0.100 * * * \\
(0.036)\end{array}$ & $\begin{array}{l}0.079 * * \\
(0.039)\end{array}$ & $\begin{array}{l}0.091^{* *} \\
(0.037)\end{array}$ \\
\hline$\Delta \log ($ Labor $)$ & $\begin{array}{l}1.184 * * * \\
(0.036)\end{array}$ & $\begin{array}{l}1.193 * * * \\
(0.035)\end{array}$ & $\begin{array}{l}1.177 * * * \\
(0.036)\end{array}$ & $\begin{array}{l}1.189 * * * \\
(0.034)\end{array}$ & $\begin{array}{l}1.179 * * * \\
(0.036)\end{array}$ & $\begin{array}{l}1.186^{* * *} \\
(0.035)\end{array}$ & $\begin{array}{l}1.182 * * * \\
(0.036)\end{array}$ & $\begin{array}{l}1.189 * * * \\
(0.035)\end{array}$ \\
\hline Metal & $\begin{array}{c}0.304 * \\
(0.158)\end{array}$ & $\begin{array}{c}0.276^{*} \\
(0.141)\end{array}$ & $\begin{array}{c}0.274^{*} \\
(0.159)\end{array}$ & $\begin{array}{c}0.261 * \\
(0.142)\end{array}$ & $\begin{array}{l}0.369 * * \\
(0.158)\end{array}$ & $\begin{array}{l}0.332 * * \\
(0.143)\end{array}$ & $\begin{array}{l}0.339 * * \\
(0.156)\end{array}$ & $\begin{array}{l}0.286^{* *} \\
(0.144)\end{array}$ \\
\hline Chemical & $\begin{array}{c}0.212 \\
(0.176)\end{array}$ & $\begin{array}{c}0.213 \\
(0.174)\end{array}$ & $\begin{array}{c}0.200 \\
(0.178)\end{array}$ & $\begin{array}{c}0.206 \\
(0.175)\end{array}$ & $\begin{array}{c}0.239 \\
(0.178)\end{array}$ & $\begin{array}{c}0.233 \\
(0.175)\end{array}$ & $\begin{array}{c}0.229 \\
(0.178)\end{array}$ & $\begin{array}{c}0.218 \\
(0.176)\end{array}$ \\
\hline Machine building & $\begin{array}{l}0.269 * * \\
(0.107)\end{array}$ & $\begin{array}{l}0.278^{* * *} \\
(0.106)\end{array}$ & $\begin{array}{l}0.265^{* *} \\
(0.107)\end{array}$ & $\begin{array}{l}0.276^{* * *} \\
(0.106)\end{array}$ & $\begin{array}{l}0.288 * * * \\
(0.109)\end{array}$ & $\begin{array}{l}0.293 * * * \\
(0.108)\end{array}$ & $\begin{array}{l}0.285^{* * *} \\
(0.109)\end{array}$ & $\begin{array}{l}0.290 * * * \\
(0.108)\end{array}$ \\
\hline Light\&food & $\begin{array}{l}0.214^{* *} \\
(0.109)\end{array}$ & $\begin{array}{c}0.210^{*} \\
(0.108)\end{array}$ & $\begin{array}{c}0.212 * \\
(0.109)\end{array}$ & $\begin{array}{c}0.210^{*} \\
(0.108)\end{array}$ & $\begin{array}{l}0.237 * * \\
(0.111)\end{array}$ & $\begin{array}{l}0.231^{* *} \\
(0.110)\end{array}$ & $\begin{array}{l}0.232^{* *} \\
(0.111)\end{array}$ & $\begin{array}{l}0.225^{* *} \\
(0.110)\end{array}$ \\
\hline Service & $\begin{array}{l}0.897 * * * \\
(0.191)\end{array}$ & $\begin{array}{l}0.903 * * * \\
(0.192)\end{array}$ & $\begin{array}{l}0.917 * * * \\
(0.190)\end{array}$ & $\begin{array}{l}0.925^{* * *} \\
(0.191)\end{array}$ & $\begin{array}{l}0.929 * * * \\
(0.192)\end{array}$ & $\begin{array}{l}0.933 * * * \\
(0.192)\end{array}$ & $\begin{array}{l}0.909 * * * \\
(0.192)\end{array}$ & $\begin{array}{l}0.914 * * * \\
(0.192)\end{array}$ \\
\hline Kyiv & $\begin{array}{l}0.535^{* * *} \\
(0.126)\end{array}$ & $\begin{array}{l}0.533 * * * \\
(0.126)\end{array}$ & $\begin{array}{l}0.531 * * * \\
(0.126)\end{array}$ & $\begin{array}{l}0.531 * * * \\
(0.126)\end{array}$ & $\begin{array}{l}0.547 * * * \\
(0.129)\end{array}$ & $\begin{array}{l}0.549 * * * \\
(0.129)\end{array}$ & $\begin{array}{l}0.549 * * * \\
(0.130)\end{array}$ & $\begin{array}{l}0.551^{* * *} \\
(0.130)\end{array}$ \\
\hline $\mathrm{R}^{2}$ & 0.57 & & 0.56 & & 0.57 & & 0.57 & \\
\hline First stage F-statistic & 75.9 & & 69.3 & & 87.2 & & 84.2 & \\
\hline AR statistic & 5.233 & & 7.026 & & 4.45 & & 5.692 & \\
\hline $\begin{array}{l}\text { Hausman test: } \mathrm{p} \text {-value } \\
\rho\left(\varepsilon_{i}, u_{i}\right)\end{array}$ & 0.025 & $-0.366^{* * *}$ & 0.006 & $-0.394 * * *$ & 0.038 & $-0.378 * * *$ & 0.016 & $-0.420 * * *$ \\
\hline Wald $\chi^{2}$ & & 1787.1 & & 1807.7 & & 1771.4 & & 1766.7 \\
\hline $\log L$ & & -3443.04 & & -3455.4 & & -3384.6 & & -3377.88 \\
\hline
\end{tabular}

Note: The table presents estimates of specification (7) with alternative correction for endogeneity of oligarch ownership. Specifications 1 through 4 have the selection equation that corresponds to the specification reported in Table 5. Dependent variable is the change in log value added between 1993 and 2002. IV and SEL are instrumental variables and selection-corrected treatment effect estimators, respectively. Robust standard errors are in parentheses. Omitted industry is energy. Definitions of the variables are in the text. *,**, *** significant at 10\%, 5\%, and 1\% respectively. AR is the Anderson-Rubin statistic with critical values computed as in Moreira (2003). Critical value for the AR statistic are 3.84 and 5.41 for 5\% and 1\%, respectively (500 simulations). Number of observations is 1,917 . 
Table 7. Matching estimator.

\section{Oligarch dummy}

\begin{tabular}{ccccc} 
Treatment & Baseline & Specification 1 & Specification 2 & Specification 3 \\
\cline { 2 - 5 } & $(1)$ & $(2)$ & $(3)$ & $(4)$ \\
\hline \hline OLIGARCH & $0.463^{* * *}$ & $0.455^{* * *}$ & $0.389^{* * *}$ & $0.409^{* * *}$ \\
& $(0.129)$ & $(0.124)$ & $(0.127)$ & $(0.121)$ \\
\hline \hline
\end{tabular}

Note: The table present estimates of the Abadie-Imbens non-parametric matching estimator of the treatment effect. Dependent variable is the change in log value added between 1993 and 2002. In the baseline specification, the list of variables on which firms owned by oligarchs are matched to firms not owned by oligarchs is the set of right hand side variables in specification (6). In Specification 1, the list of matched characteristics is equal to the set in the baseline specification plus investment-to-capital ratio in 1993. In Specification 2, the list of matched characteristics is equal to the set in the baseline specification plus liquidity of output in 1993. In Specification 3, the list of matched characteristics is equal to the set in the baseline specification plus investment-to-capital ratio and liquidity of output in 1993. We do not match firms on deterministic transformations of the variables. Number of observations is 1,917 . 
Figure 1. Indices of gross domestic product, investment and manufacturing.

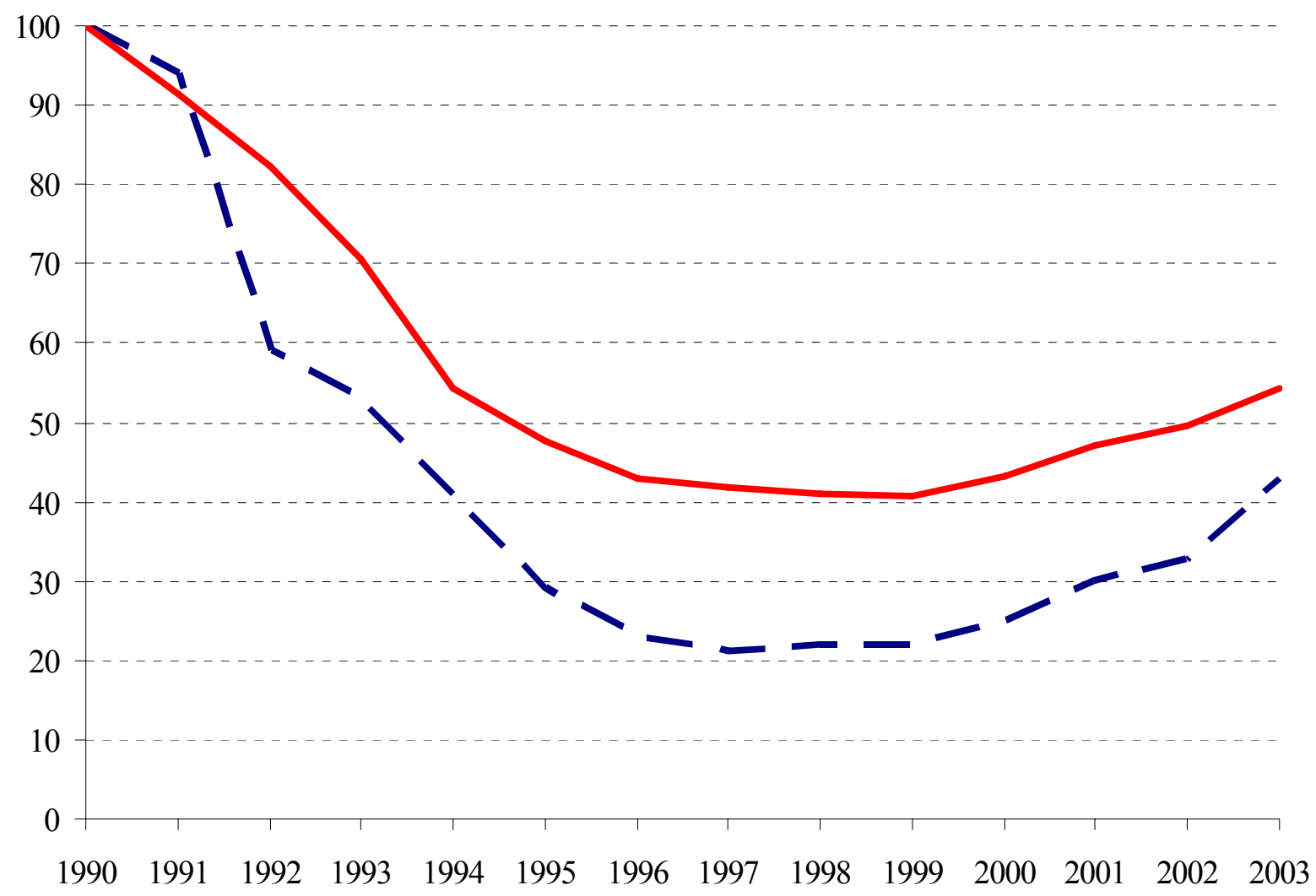

Note: solid denotes GDP, long-dash denotes the index of investment in plant, equipment, and structures. Source: State Statistics Committee of Ukraine. 
Figure 2. A branch of a conglomerate owned by a Ukrainian oligarch.

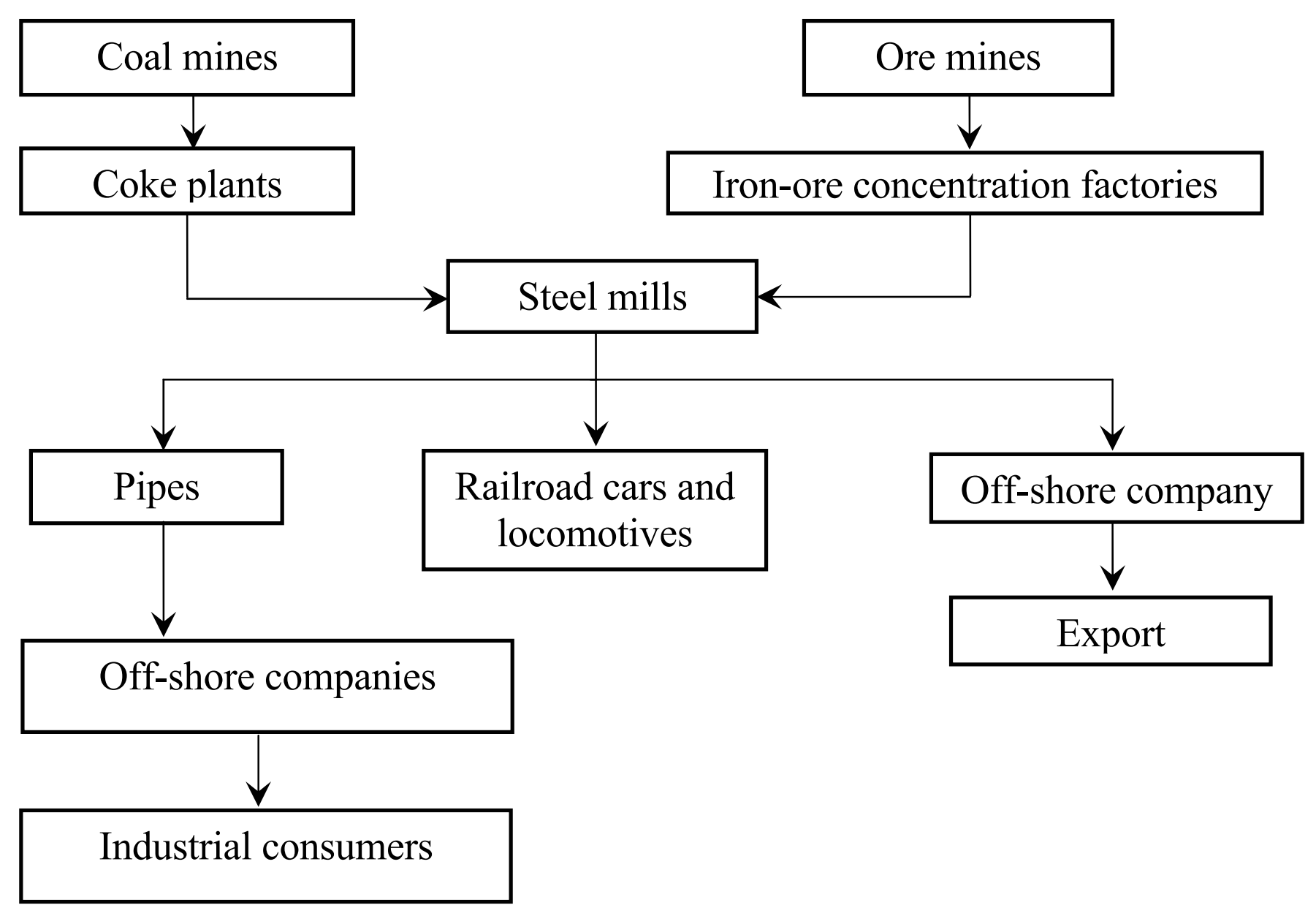

